\title{
III. Haçlı Seferi Öncesinde Diplomasi Ve Alman Ordusunun Balkan Topraklarındaki Yolculuğu Üzerine
}

\section{On The Diplomacy Before The Third Crusade and The Campaign of German Forces in The Balkan Region}

\author{
Aydın Usta'
}

'Sorumlu yazar/Corresponding author: Aydın Usta (Prof. Dr.), Mimar Sinan Güzel Sanatlar Üniversitesi, Fen-Edebiyat Fakültesi, Tarih Bölümü, İstanbul, Türkiye. ORCID: 0000-0002-6639-5880

Bașvuru/Submitted: 08.02.2021 Kabul/Accepted: 05.05.2021

Atıf/Citation: Usta, Aydin, “III. Haçlı Seferi Öncesinde Diplomasi ve Alman Ordusunun Balkan Topraklarındaki Yolculuğu Üzerine" Güneydoğu Avrupa Araștırmaları Dergisi, 36 (2021), s. 57-81

https://doi.org/10.26650/gaad.876738

\section{öz}

Kudüs'ün 1187 senesinde Sultan Salâhaddîn tarafından zaptını müteakip Avrupa'da başlayan Doğuya yapılacak yeni bir Haçlı Seferi hazırlıklarının en önemli simalarından biri de Kutsal Roma-Germen İmparatoru I. Frederich Barbarossa'dır. Deniz yolunu tercih eden İngiliz ve Fransız krallarının aksine kara güzergâhını seçen I. Frederich aynı zamanda Sultan Salâhaddîn'in en çok çekindiği isimdi. Gerekli hazırlıkların tamamlanmasından sonra Nisan 1189 'da Regensburg'tan yola çıkan Alman İmparatorunun iki aşamalı sefer yolculuğunun ilk safhası ise Balkan geçişidir. Çanakkale Boğazı'na kadar devam eden bu güzergâhta Alman Ordusu, Macar topraklarından çıkıp o sırada isyanlarla çalkalanmakta olan Bizans topraklarına girmiştir. Burada civardaki haydutların saldırıları kadar seferin kendi üzerine dönmesinden endişelenen Bizans İmparatoru II. Isaakios Angelos'un engellemelerinin de muhatabı olmuştur. Bu çalışmamızda I. Frederich ve emrindeki Alman ordusunun yürüyüşleri sırasında başlarından geçen olaylar ve öncesinde yaşanan diplomasi faaliyetleri ele alınmıştır.

Anahtar Kelimeler: I. Frederich, Salâhaddîn, II. Isaakios, III. Haçlı Seferi, Diplomasi

\section{ABSTRACT}

One of the most important pillars of the preparations for a new Crusade to the East, which began in Europe in 1187 after Jerusalem was seized by Sultan Șalāh al-Dīn, is the Holy Roman-Germen Emperor Frederich Barbarossa I. Unlike the British and French kings who preferred the sea route, Frederich I chose the land route, and was also the name sultan Șalāḥ al-Dīn was most afraid of. After the completion of the necessary preparations, the first phase of the German Emperor's two-stage expedition journey from Regensburg in April 1189 is the Balkan crossing. On this route to the Dardanelles, the German Army left Hungarian territory and entered byzantine territory, which 
was awash with riots at the time. Here, as much as the attacks of the nearby bandits, German have also been the interlocutor of the Byzantine Emperor II Isaakios Angelos who was concerned that the expedition would turn on him. This study focused on the events that happened during the marches of Frederich I and the German army under his command, and the previous diplomatic activities..

Keywords: I. Frederich, Șalāḥ al-Dīn, II. Isaakios, Third Crusade, Diplomacy.

\section{EXTENDED ABSTRACT}

The wave of excitement and concern that surrounded Europe after the conquest of Jerusalem by Șalāh al-Dīn b. Ayyūb on 2 October 1187, also heralded a new Crusade to the East. People made their preparations to take back Jerusalem, which they regard as the holiest place of Christianity, and took action from land and sea. The Holy-Roman Emperor Frederich Barbarossa also set out by land with his strong and crowded army, unlike the English and French kings who preferred to go by sea. Emperor Frederich thought that his army would be able to advance along the way without any difficulties, thanks to a number of diplomatic activities he carried out before her movement.

That is why, long before, he wrote a letter to Sultan Șalāh al-Dīn and invited him to fight in the Zoan Plain if he did not give Jerusalem back to Christianity. However in spite of the guarantees given by the Byzantine both the Saldjuks in Turkey to Germans they showed from the very beginning that they did not intend to leave the Germans alone freely.

In our study will be explained that events which the German Crusaders of the Third Crusade which encountered in the Byzantine land in the Balkans constitute the second stage of the journeys.

So much so that the German army has faced many difficulties since entering here. In addition to the risk of epidemic disease caused by swamp lands and mosquitoes, the attacks of bandits of different ethnic identities, which they have thought the Byzantines were guided by, caused losses to them. Even after the tension in the relations, the Byzantine Imperial Army started to intervene in the situation itself. Meanwhile, Serbs and Bulgarians, who were waiting for the opportunity to leave the empire's nationality and want to gain land in the Balkans, They wanted to provoke Frederich Barbarossa, against II. Isaakios and direct the expedition to Istanbul. On the other hand, this hostile attitude of Byzantium was enough to anger the Germans who were already prejudiced against them. For this reason, they thought that they were acting together with Muslims against them. As a matter of fact, in the sources we have dealt with in relation to this, there is information that they acted in this way because they had an alliance with Șalāḥ al-Dīn b. Ayyūb.

However, Emperor II. Isaakios Angelos realizing that did not have much of a chance against the dominant power of the German Crusaders ultimately chose to make an agreement with his interlocutor. Thus, the German Army, with Byzantine hostages, passed through the Dardanelles after a five-day effort, and they started the third phase of their journey. 
XI. yüzyılın sonlarında başlayan Haçlı Seferlerinin iki ana motivasyon unsurundan biri “Doğulu Hıristiyan kardeşlere” yani Bizans'a yardım olarak ifade edilmiş olsa da iki yüz yılı bulan seferler tarihindeki gelişmelerin bundan bir hayli farklı tezahür ettiği aşikardır. Zira Büyük Roma İmparatorluğunun siyasî mirasının yegâne hak sahibi olmak pozisyonuna karşın belki de yer aldığı coğrafyanın etkisiyle aslî kimliğinden giderek uzaklaşan Bizans ile Batı dünyası arasındaki uçurum seferlerin başladığı dönemlerde ciddi boyutlara ulaşmıştı. Özellikle 1054'te gerçekleşen Schisma iki taraf arasındaki kutuplaşmanın mezhepsel yönünün en keskin tezahürüydü.' Zira Ortodoksluk ve Katoliklik arasındaki dinî bir çatışma olarak görünen söz konusu ayrılık diğer taraftan Batı'daki yeni iktidar sahiplerinin Bizans'ın siyasî varlık ve miras söylemlerine duydukları tepkinin açık bir ifadesiydi.

451 'deki Kadiköy Konsilinde dönemin İmparatoru Marcianus'un (450-457) daha çok siyasî gayelerine hizmet üzere gerçekleştirdiği İstanbul Patrikliğini, Roma Kilisesine eşitlemek hamlesi söz konusu mezhepsel ayrılığı beraberinde getirse de Batı dünyası ilerleyen zamanlar içinde bunu Bizans'ı, kendi siyaset sahasından uzaklaştırmak adına bir bahane yapmıştır. Papa III. Leo tarafından 800 senesinde Charlemagne'ye imparatorluk unvanının verilmesi de bahse konu siyasetin bir ürünüdür.

Ancak Bizans için 1071'de Malazgirt'te uğradığı mağlubiyet; Batıdan askerî destek (paralı asker) bulmayı gerekli kılarken, aklında uzun zamandan beridir uygulamaya koymak istediği çok daha başka planları olan Papalığın önüne de önemli bir fırsat çıkarmıştır. Böylece görünürde Kudüs hedefi ile Avrupa'dan harekete geçen Haçlı kitleleriyle Bizans arasında zahirî dostluk gösterilerinin yaşandığı fakat gerçekte karşııklı menfaatlerin ön plana çıktığı bir diplomasi oyunu başlamıştır. Öyle ki başlangıcından İstanbul'un 1204 'teki işgaline kadar geçen süreçte taraflar asıl meşgalelerinin yanında aynı zamanda yekdiğerini kollamak için ciddi mesai sarf etmişlerdir.

Çünkü bu dönemde Bizans imparatorlarının, Haçlılarla olan ilişkilerindeki en büyük endişeleri karşıdakilerin bir fırsatını bulup başkentlerini ele geçirmesi ihtimali olmuştur. Elbette ki onların zihinlerinden hiçbir zaman çıkmayan bu kaygılarını tetikleyen olaylar da seferler boyunca eksik olmamıştır. Durum böyle iken Batıdan gelen kardeşlerine karşı yeri geldiğinde aynı coğrafyayı paylaştıkları unsurlarla kader birliği yapmaları gayet olağan hale gelmiştir.

1187 yılına gelindiğinde başta Kudüs olmak üzere yaşanan toprak kayıpları aslında bir süredir kenara itildiği görülen Haçlı ruhunun yeniden canlanmasını sağlamıştı. Bu vesileyle Avrupa'nın her yerini saran Ortadoğu'ya doğru yeni bir sefer heyecanı tabi olarak Bizans'ı da yakından ilgilendirmekteydi. Ancak daha 1176'da Türkiye Selçukluları karşısında uğradığı ağır yenilginin yaralarını sarmadan eski düşmanları Normanlardan gelen bir istila tehdidini

1 Georg Ostrogorsky, Bizans Devleti Tarihi, çev. Fikret Işıltan, Ankara: TTK, 1995, s. 310-312; John Julius Norwich, Bizans II, Yükseliş Dönemi (MS. 803-1081), çev. Selen Hırçın Riegel, İstanbul: Dünya Yayınları, 2013, s. 250-255; Averil Cameron, The Byzantines, Oxford: Princeton University Press, 2006, s. 44-45; Aydın Usta, Sorularla Bizans Imparatorluğu, İstanbul: Yeditepe Yayınevi, 2016, s. 145-146. 
karşılamak zorunda kalan yaşlı imparatorluğun siyasî-askerî durumu pek de iyi sayılmazdı. Üstelik yakın zamanda bir hanedan değişikliği yaşamış ve kendisine belki de son ihtişamlı günlerini yaşatan Komnenoslar tahttaki yerlerini zayıf Angeloslara bırakmışlardı. Böylesi bir ortamda Avrupa'dan Kudüs hedefiyle başlatılan ve Bizans topraklarından geçecek her askerî gücün onlar için sıkıntı kaynağı teşkil etmesi, eski defterlerin de halen göz önünde olduğu düşünüldüğünde son derece doğal bir durumdu. Bu çalışmamızda bahse konu seferin öncesinde gerçekleşen devletlerarası diplomasi ve bunun seferin kara ayağını oluşturan İmparator I. Frederich Barbarossa'nın idaresindeki Alman Ordusunun, Kudüs hedefiyle çıktığı yolculuğunda Balkan geçişi sırasında yaşanan gelişmelere olan etkisi ele alınmaya çalışılacaktır.

Bizans'ın Haçlı hareketinin başladığı dönemden itibaren Batıdan gelen dindaşlarıyla arası hiçbir zaman gerçek manasıyla iyi olmamıştı. Öyle ki Bizans bu seferlerin ana hareket temalarından biri olan Doğulu Hıristiyan kardeşlere yardım söyleminin temelsizliğini daha başlangıçta onların İstanbul surlarına yaptığı saldırılar dolayısıyla gayet iyi bir şekilde anlamıştı. Nitekim zamanın imparatoru I. Aleksios Komnenos'un bu sıralarda yaşadığı endişeler kızı Anna Komnena'nın kaleme aldığı eserinde açık şekilde ifade edilmektedir. ${ }^{2} 1107-1108$ yılları arasında İmparatorluğun Balkan topraklarındaki en stratejik şehirlerinden biri olan Draç üzerine yönelen Haçlı saldırısı ise söz konusu endişelerin gerçeğe dönüşmesi olmuştur. Haliyle Bizans, Avrupa siyaset sahnesindeki yalnızlığı telafi etmek adına kendisine yeni müttefikler bulmak arayışına girmiştir. Neticede ticarî imtiyazlar karşıığında Venediklilerden ve komşu Türkiye Selçuklularından alınan destek ile Batılı kardeşlerinin gerçekleştirdiği ilk fiili saldırıyı bertaraf edebilmiştir. ${ }^{3}$

Öte yandan Bizans'ın 1071 yılı sonrasında başlayan Anadolu coğrafyasını Türklerle paylaşmak gerçekliği zamanla belli bir ortaklık ve bir arada yaşam tecrübesini de beraberinde getirmiştir. İki taraf içinde yeni bir durum olan bu yeni düzen ve komşuluk ilişkileri Bizans için Türkleri, Haçlılara nazaran daha bilindik ve ehven-i şer kılmaktaydı. Nitekim bu gerçeklik Niketas Khoniates'in ağzından biraz farklı da olsa şu şekilde dökülmüştür;

Imparator Manuel'e göre Doğulu halkları para ya da silah gücüyle kendi tarafına çekmek mümkündü....... Fakat türlü sebeplerle çok yaygın topraklarda oturan batılı milletlerden korkuyordu. Çünkü bunlar dik başlı ve inatçıydılar. Bunların kana susamışlıkları çok ileri bir derecededir ve bu duygularının körleşmemesi için durmadan çaba harcarlar. Etrafları daima servetle çevrili olmakla ve sadece bütün silah çeşitlerine malik olmakla kalmayıp bunlar sürekli olarak Bizans'ın kötülüğünü istemektedirler; daima isyankâr, Bizanslılara şaşı bakan ve kabadırlar. ${ }^{4}$

2 Anna Komnena, Alexiad, Malazgirt'in Sonrası, çev. Bilge Umar, İstanbul: İnkılap Kitabevi, 1996, s. 303, 305, 314-315.

3 Anna Komnena, a.g.e., 371-373, 385-388; Steven Runciman, Haçlı Seferleri Tarihi, II, çev. Fikret Işıltan, Ankara: TTK, 1992, s. 40-42; Ebru Altan, "Bizans'a Karşı İlk Haçlı Seferi Girişimi ve 1108 Devol Anlaşması", Prof. Dr. Mehmet Ipşirli Armağanı, I, İstanbul: Timaş Yayınları, 2013, s. 107-117; Usta, a.g.e., s. 163-164; aynı mlf., Çıkarların Gölgesinde Haçıı Seferleri, İstanbul: Yeditepe Yayınevi, 2016, s. 146-149.

4 Niketas Khoniates, Historia (loannes ve Manuel Komnenos Devirleri), çev. Fikret Işıltan, Ankara; TTK, 1995, s. 139. 
Nitekim Sicilya Normanları daha Haçlı Seferlerinin öncesinde imparatorluğun Balkanlardaki arazine karşı ciddi bir istila hareketi gerçekleştirmişlerdi. Bunlar Avrupa'daki Bizans karşıtı hareketin başını çekmekteydiler. Mezhepsel konulardan mütevellit Papalıkla, imparatorluk unvanının kullanımı sebebiyle de Almanlarla ilişkiler her daim pamuk ipliğine bağlı bir haldeydi. Macarlarla Balkanlar meselesi yüzünden zaten genel bir savaş hali mevcuttu. Avrupa'daki bir başka önemli siyaset ve güç unsuru olan Fransa Krallığı, Bizans'ın üzerine ilk haçlı seferini düzenleyen Bohemund'un en büyük destekçilerinden biri olmuştu. Ayrıca fiyaskoyla neticelenen II. Haçlı Seferinin ardından da Sicilyalıların kurduğu ittifakın en etkin üyelerinden biri durumuna gelmişlerdi.

Mamafih devletlerarasındaki ilişkilerde dostluk ya da düşmanlık ile alakalı hassas denge, siyasî çıkarların nerede ve nasıl kesiştiği ile yakından alakalıdır. Almanların, papalık ile geleneksel düşmanlıkları, Normanlar ile İtalya üzerindeki rekabetleri Bizans'a Avrupa diplomasisinde kendi adına bir denge kurmak imkânını sağlamıştır. Öyle ki Sicilya Normanlarının el altından siyasî rakipleri olan Welf'leri maddî anlamda desteklemelerine içerleyen III. Konrad, Bizans ile yakınlaşmayı tercih etmiştir. Venedik ise ticarî bağlantıları ve Normanların Akdeniz'de artan etkisinden duyduğu kaygı sebebiyle bu ittifaka dâhil olmuştur. ${ }^{5}$ Ancak III. Konrad'ın 1152'de ölümü ve İmparator Manuel'in üç sene sonrasında İtalya'nın kuzeyinde gerçekleştirdiği askerî harekât yeni Alman İmparatoru I. Frederich Barbarossa ile aranın bozulmasına yetmiştir.

İtalya'daki Alman çıkarları konusunda son derece hassas olan I. Frederich derhal papalık ile Bizans'ın, buradaki varlığına hiçbir şekilde müsamaha göstermeyeceği hususunda bir anlaşma yapmıştır. Bu arada imparatorluğun uzun bir aradan sonra İtalya'da faaliyet göstermesi diğer müttefik Venedik ile olan ilişkilerin de bozulmasına yol açmıştır. Bizans adına felaketi tamamlayan ise başlangıçta kazanılan bazı başarılara karşın İtalya'da Sicilya Normanları karşısında uğranılan mağlubiyet olmuştur. Neticede imparatorluk 1158'de buradan tamamıyla çekilmek zorunda kalmıştır. Söz konusu olaylar silsilesi aynı zamanda Bizans'ın Avrupa siyasetinde var olmak konusundaki son çabasıdır ve kesin bir hüsran ile neticelenmiştir. ${ }^{6}$

Batıda siyaset ve diplomasi sahasında yaşanan bu değişkenlikler doğudaki hâkimler için de çok yabancı bir durum değildi. Bizans'ın doğu komşusu Türkiye Selçukluları, imparatorlukla olan münasebetlerinin dışında kuruldukları tarihten itibaren Güneydoğu Anadolu ile Kuzey Suriye'de hâkimiyet kurmak için yoğun bir mesai harcamışlardır. Bu sebeple de evvela Büyük Selçuklular sonrasında ise sırasıyla Zengîler ve Eyyûbîlerle karşı karşıya gelmişlerdir. Ancak burada da dengeler Batıda olduğu gibi her daim pamuk ipliğine bağlı olmuş ve sürekli şekilde değişkenlik gösterebilmiştir.

Diğer taraftan başkentinin yer aldığı konum Bizans adına batıda olduğu kadar doğu siyasetinin de içinde olmak zorunluluğunu beraberinde getirmekteydi. Dolayısıyla her şartta

5 Ostrogorsky, a.g.e., s. 354-355; John Julius Norwich, Bizans, III, Gerileme ve Çöküş Dönemi (MS. 1082-1453), çev. Selen Hırçın Riegel, İstanbul: Kabalcı Yayınevi, 2013, s. 111.

6 Ostrogorsky, s. 355-357; Norwich, III, s. 117-122. 
bu taraftaki siyasî gelişmelerin içinde bulunmak gayretinde olmuş ve mevcut durumu kendi çıkarlarına göre yönlendirmeye çalışmıştır. Örneğin II. Kılıç Arslan iktidarının hemen başlarında Danişmentli-Bizans-Zengî ittifakı karşısında yaşadığı çaresizliği Bizans'ın bazı siyasî-askerî gereksinimler sebebiyle kendisine yanaşması sayesinde atlatabilmiştir.7 Öte yandan bu ittifakın diğer bir güçlü üyesi Zengîlerin temel gayesi ise Türkiye Selçuklularını Güneydoğu Anadolu ve Kuzey Suriye'den mümkün olabildiğince uzak tutmak olmuştur. Onların bu siyaseti ardılları Eyyûbîler tarafından da gayet dikkatli bir şekilde devam ettirilmişti. ${ }^{8}$

Söz konusu durum haliyle Türkiye Selçuklularına karşı bir Bizans-Eyyûbî yakınlaşmasını da beraberinde getirmiş̧i. Zira Avrupa'daki diplomatik yalnızlığı, doğuda her geçen gün büyümekte olan Selçuklu tehdidi böyle bir ittifakı Bizans için bir zorunluluk durumuna sokmaktaydı. Manuel Komnenos'un veliahtı Il. Aleksios adına imparatorluğu idare eden Protosebastos Aleksios 1181 yazında Kahire'ye elçiler göndermek suretiyle ilk adımı atmış ve iyi niyetinin bir göstergesi olarak da 180 Müslüman esiri serbest bırakmıştı. ${ }^{9}$ Ardından Komnenosların son üyesi Andronikos da 1183'teki elçilik teatisi ile sağlanan mutabakat ve ortaklığı devam ettirmişti. ${ }^{10}$

Bununla birlikte daha sonrasında Angeloslar tarafından da devam ettirilecek bu anlaşmanın kaynaklar tarafından bize aktarılan şartlarında o günün siyasî-askerî gerçeklikleriyle bağdaşmayan bazı durumlar vardır. Öyle ki Salâhaddîn'in, Haçlıları yenmeyi başardığı takdirde kazanacağı zaferinin asıl meyvesi Kudüs'ü ve Askalân'a kadar olan kıyı bölgesinin yanında

7 Türkiye Selçuklularının en büyük hükümdarlarından biri olan II. Kılıç Arslan tahta çıkmasından hemen sonra yüzleşmek zorunda kaldığı neredeyse bütün komşularının yer aldığı böylesi bir ittifak tehdidinden bizzat İstanbul'a giderek İmparator Manuel ile görüşmek suretiyle kurtulabilmiştir. Zira adı geçen imparator, Macarların Balkanlardaki tehdidine son vermek gereksinimi sebebiyle geride kendisine sıkıntı çıkaracak bir güç bırakmamak adına Sultan ile anlaşmayı tercih etmişti. Ayrıca Danişmendlilerin, Türkiye Selçuklularının egemenliğini tamamıyla sııırlayacak şekilde güçlenmesi de Bizans için pek fazla istenilen bir durum değildi. Dolayısıyla da Bizans bahse konu ittifaktan ayrılıp Selçuklularla anlaşmayı tercih etmişti. Bkz., loannes Kinnamos, Historia, çev. Işın Demirkent, loannes Kinnamos'un Historia'sı (1118-1176), Ankara: TTK, 2001, s. 145-151; Osman Turan, Selçuklular Zamanında Türkiye, İstanbul: Boğaziçi Yayınları, 1993, s. 200-202; Usta, Sorularla Bizans, s. 182-183.

8 Nûreddîn Mahmud bunun için Türkiye Selçuklularına karşı Danişmendlileri korumak suretiyle hamle yapmayı tercih ederken Salâhaddîn Eyyûbî de, II. Kııı̧ Aslan ile damadı Hısn-ı Keyfa Artuklu Hâkimi Nûreddîn Muhammed arasında ailevi olarak kabul edebileceğimiz bir meseleye müdahil olarak benzer şekilde bir tutum sergilemiştir. Bkz. Turan, a.g.e., s. 211-212; Aydın Usta, Doğunun ve Batının Hakimleri, Selçuklular (Gerçek Hikayeler ve Anekdotlar), İstanbul: Yeditepe Yayınevi, 2019, s. 187-189.

9 Makrizî, es-Sulûk li-ma'rifeti düveli'l-müluk, I, thk. Muhammed Abdülkadir Ata, Beyrut 1997, s. 185.

10 Chronicon Magni Presbyteri, Annales Reicherspergenses, ed. W. Wattenbach, Monvmenta Germaniae Historica (MGH), XVII, ed. G. H. Pertz, Hannover 1861, s. 511; çev. G. A. Loud, The Crusade of Frederick Barbarossa The History of Expedition of the Emperor Frederick and Related Text, Burlington: Ashgate Publishing, 2010, s. 152153; Jonathan Phillips, Defenders of the Holy Land, Relations between the Latin East and the West 1119-1187, Oxford: Oxford University Press, 1996, s. 251; Bernard Hamilton, The Leper King and his Heirs, Baldwin IV and the Crusader Kingdom of Jerusalem, Cambridge: Cambridge University Press, 2000, s. 170; Charles M. Brand, "The Byzantines and Saladin 1185-1192: Opponents of the Third Crusade" Speculum, vol. 37, no. 2 Nisan 1962, s. 167-169; Savvas Neocleous, "The Byzantines and Saladin: Some Further Argument", Al-Masaq: Islam and Medieval Mediterranean, 25:2, 2013, s. 205-206, 210; aynı mlf. "Byzantine-Muslim Conspiracies Against the Crusades: History and Myth", Journal of Medieval History, 36 (2010), s. 267-268. 
Ermenileri sınırına kadar Konya sultanına ait olan topraklarını ele geçirip Bizans'a vermeyi kabul ettiği ifade edilmektedir. Bir diğer ilginç husus ise gerek Andronikos ve gerekse Isaakios ile yapılan bu anlaşmalarda Eyyûbî hükümdarının, muhataplarının en sevgili tabii (homini suo dilectissimo) olarak ifade edilmesidir." Bahse konu durumu kaynağın bölgeye ve dolayısılla siyasî konjonktürüne uzak olmasının bir sonucu gibi görmek mümkündür. Ancak Bizans'ın mevcut haliyle karşısındakine böyle bir şeyi dikte edip taviz koparabilecek durumu olmadığı aşikârdır. Diğer taraftan söz konusu anlaşmada bazı dönemlerde adı konulmasa da aslında seferlerin başından itibaren var olan de facto bir durumdur ${ }^{12}$ ve III. Haçlı Seferi boyunca iki taraf arasında gerçekleşen yazışmaların içeriğinde de kendisini açıkça belli etmiştir.

Öte yandan bölgenin en güçlü iki devleti (Türkiye Selçukluları-Eyyûbîler) arasındaki ilişkinin salt bir düşmanlık ve rekabetten ibaret olmadığını da burada ifade etmek gerekmektedir. Nitekim iki devletin siyasetteki bütün çekişmelerine karşın Sünnî İslam ve Cihad ortak paydalarında yolları kesişmekteydi. Her türlü rekabetin üzerinde ve kendine has (su generis) olan bu iki husus ahalinin de baskısıla aynı zamanda ciddi bir kamuoyu meydana getirmekteydi. Öyle ki iki tarafın arasının II. Kılıç Arslan'ın damadı Hısn-ı Keyfa Artuklu Hâkimi sebebiyle bozulduğunda Salâhaddîn'in Anadolu üzerine yürümek isteğini birincisinin veziri bu gerçekliği vurgulayarak engellemiştir (1180). ${ }^{13}$ Ayrıca kara yönünden Ortadoğu üzerine gelecek herhangi bir Haçı tehdidinde daha evvelkiler de olduğu gibi Türkiye Selçuklularının burada oynayacağı kalkan rolü Salâhaddîn için de önemli idi. Dolayısıyla aktardığımız bu olayın akabinde taraflar arasındaki ilişkinin nispeten düzeldiği görülmektedir. Hatta Salâhaddîn'i 1187'de Kudüs'ü almasının sonrasında ilk tebrik edenlerden biri de II. Kıııc Arslan olmuş ve bu iş için bizzat

11 Chronicon Magni Presbteri, aynı yer.

12 Bu konudaki farklı görüşlerin varlığına karşın (bkz. Neocleus, The Byzantines and Saladin”, s. 204-221; aynı mlf. Byzantine-Muslim Conspiracies", s. 270-271) böyle bir ortaklığın coğrafyaya bağlı siyasî-askerî çıkarların bir gereği şeklinde yorumlanmasının daha doğru olacağını düşünmekteyiz. Zira Batılı kroniklerde geçen gerçeklik ihtimali bulunmayan bilgilerin (Salâhaddîn'in Bizans'a tabiyeti, Bizans'a toprak vermesi, zehir olayı vd.) varlığına karşın hepsinin ortak paydasının Batı'dan gelenlere karşı öyle ya da böyle Doğuluların birlikteliğine olan vurgudur. Aslında bu durumun başka bir örneğini Akka kuşatması sırasında Doğulu Haçlıların liderliğini üstlenen Konrad de Montferrad ile Selahaddin arasında yapılan İngiltere Kralı Richard'ın aleyhine yazışmalarda da görmek mümkündür. (Bkz. İbn Şeddad, İbn Şeddad, en-Nevadir es-Sultaniyye fi'l-Mehasin el-Yusufiyye, thk. Cemal Şeyyal, Kahire: Mektebet'ül-Hâncî, 1994, s. 190, çev. D. S. Richards, The Rare and Excellent History of Saladin, Burlington: Ashgate Publishing, 2002, s. 182) Bu türden misalleri çoğaltmak mümkündür. Alman İmparatorunun gerçekten de Filistin'e gitmek niyetinde olmasına karşın, II. Isaakios'un yaşadığı endişe ve korkuları da bir histeri nöbeti şeklinde değil yukarıda da ifade ettiğimiz üzere iki taraf arasında geçmişte yaşanan olumsuzlukların bir neticesi kabul etmek gerekir. Bir başka ifade ile doğal bir reaksiyondur.

13 Eyyûbî Sultanı büyük bir öfke ile Anadolu üzerine yürüyüp burasını ele geçireceğini ifade ettiğinde İhtiyareddîn Hasan: Ey Efendimiz, senin gibi bir sultana yakışmaz. Sen Sultanların en büyük ve en şöhretlilerinden birisin. Halkın, senin Haçlılarla anlaşma yaptığını ve cihadı terk edip ülkenin çıkarlarını bir kenera ittiğini, sana, emrindeki halka ve bütün Müslümanlara faydalı bir işten yüz çevirdiğini, uzak yakın her taraftan asker toplayıp, senin ve askerlerinin kahpe bir şarkıcı için yollara düşüp büyük masraflar ettiğini duyması kadar büyük bir kötülük düşünebiliyor musun? Yarın Allah'a ne mazeret beyan edeceksin? Sonra halifenin, diğer Müslüman hükümdarların ve halkın nezdindeki itibarın ne olur? Onlara bunu nasıl anlatırsın? Düşün ki hiç kimse senin yüzüne karşı bunları söylemez. Fakat meselenin böyle olduğunu bilmezler mi? şeklindeki sözleriyle bu realiteyi vurgulayarak onu engellemiştir. Bkz. İbn el-Esîr, el-Kamil fi't-Tarih, XI, nşr. C. J. Tornberg, Beyrut: Dâru Sadır, 1979, s. 465. 
veziri İhtiyareddîn Hasan'ı görevlendirmiştir. ${ }^{14}$ Ayrıca İngiltere Kralı II. Henri'nin Haçlı Seferi için kolay geçiş ve ikmal imkânlarını görüşmek üzere İstanbul'a yolladığı elçiler 1188'de geri döndüklerinde efendilerine, Türkiye Selçukluları ile Eyyûbîler arasında akrabalık bağı kurulduğunu da bildirmişlerdir. ${ }^{15}$

Bölgesel olarak niteleyebileceğimiz bu ittifaklar ve devletlerarası ilişkilerin yanında III. Haçlı Seferinin hemen öncesinde daha geniş çaplı diplomasi faaliyetleri de dikkati çekmektedir. Bunlardan ilki 1179'da başlayıp sonraki yıllarda da devam edecek olan II. Kılıç Arslan ve I. Frederich arasındaki elçilik teatisidir. Bu durum Türkiye Selçuklu Sultanının, Eyyûbî-Bizans ittifakına karşıık kendisine güçlü bir müttefik bulmak çabasının bir sonucudur. Aslında II. Kılıç Arslan daha 1173 senesinde Kudüs'e yaptığı hac ziyaretinden dönen Saksonya Dükü Arslan Heinrich'i dönüş yolculuğu sırasında güzel bir şekilde ağırlamıştır. ${ }^{16}$ Burada Arslan Heinrich'in aklında II. Kılıç Arslan ile görüşmek gibi bir düşünce olmamasına karşın hasbelkader şekilde gelişen olaylar neticesinde yapılan bu görüşmenin Türkiye Selçukluları ile Kutsal Roma Cermen İmparatorluğu arasındaki diplomasinin yolunu açtığını söylemek yanlış olmayacaktır. ${ }^{17}$

II. Kılıç Arslan'ın 1179'da Almanya'ya gönderdiği elçilik heyetinin gelişini bize aktaran kaynakta, olayın Hıristiyanlığı ön plana çıkaran birtakım öğelerle süslendiği göze çarpmaktadır. Buna göre Sultan, imparatora kızını oğlu ile evlendirmesi kaydıyla halkıyla birlikte Hıristiyanlığı

14 İmâdeddîn el-Katib el-İsfahanî, el-Feth el-Kussi fi'l-feth el-Kudsî(Hurub-i Salâhaddîn ve Feth-i Beyti'l-Makdis), t.y., s. 116; Ebû Şame, Kitabü Ravzateyn fi ahbari'l-devleteyn, en-Nuriyye ve'l-Selahiyye, III, thk. Ibrahim Zeybek, Beyrut 1997, s. 415; IV, 6.

15 Roger de Hoveden, Annals of Roger de Hoveden, II, çev. Henry T. Riley, Londra, 1853, s. 99.

16 Arnoldi, Choronica Slavorum, thk. I. M. Lappenberg, in Scriptores Rerum Germanicarum, ed. G. H. Pertz, Hannover: Monvmenta Germaniae Historica, 1868, s. 22-25; E. Joranson, "The Palestine Pilgrimage of Henry the Lion", Medieval and Historiographical Essay in Honor of James Westfall Thompson, ed J. L. Cate-E. N. Anderson, Chicago, 1938, s. 196-202; Altay Tayfun Özcan, “Lübeckli Arnold'un Choronica Slavorum Adlı Eserinde Arslan Heirich'in, II. Kılıç Arslan'ı Ziyareti (1173) Bahsi ve Kayıtlarının Bazı Sorunları Üzerine”, Selçuklu Araştırmaları Dergisi, no. 1, Konya 2016, s. 191-216.

17 Zira Arnoldi (s. 30) Aslan Heinrich'in, İmparator ile görüşmeye gittiğini ve muhatabının da onun yolculuğundan sağ salim geri dönmesinden ötürü son derece sevinçli olduğunu yazmıştır (post hec abiit ad imparatorem, qui tunç erat in civitate Augusta et letatust est, multum de adventu ipsius et quia salcum illum recepit). Dolayısıyla burada Heinrich'in akrabası olan imparatora gezisiyle ilgili detayları aktardığı ve böylelikle tarafların birbirlerinden ve düşüncelerinden haberdar olduklarının düşünülmesi son derece makul görünmektedir. Öte yandan gerek Ostrogorsky (s. 361) ve gerekse Charles M. Brand (Byzantium Confronts the West 1180-1204, Cambridge 1968, s. 178) iki taraf arasındaki diplomatik diyaloğu 1173 senesinden itibaren başlatmaktadır. Runciman, (II, 328) ise bu olay hakkında tamamıyla sessiz kalmıştır. Turan (s. 221) ise münasebetleri yine aynı olay ile başlatmasına karşın 1171 tarihini vermiştir. 
kabul edeceği teklifinde bulunmuştur. ${ }^{18}$ Bahse konu tekliflerden ikincisinin gerçeklikten uzak görünmesine karşılık evlilik ile alakalı ilk teklif ise Ortaçağda devletlerarası ilişkileri geliştirmek adına başvurulan genel geçer bir kaide olması hasebiyle doğruluk payı yüksektir. Ayrıca Bizans ile I. Frederich arasındaki bozuk siyasî ilişkiler dikkate alındığında gayet mantıklı bir hamledir. Nitekim Kutsal Roma-Germen İmparatorunun, III. Haçlı Seferine çıkmak için hazırlıklarını yaptığı döneme kadar da sürdürülmüştür.

III. Haçlı Seferine doğru giden periyotta yaşanan bir diğer ilginç diplomasi ise Sultan Salâhaddîn Eyyûbî ile Papa III. Lucius (1181-1185) arasında geçen bir dizi mektuplaşmaya dairdir. 1184 yılına ait aktarımlarda verilen iki mektubun ilkinde Sultan, Oliverius Vitalis adı Papalık elçisi tarafından kendisine iletilen mektuptan duyduğu memnuniyeti ifade ettikten sonra esir mübadelesi hususundaki onayını bildirmektedir. ${ }^{19}$ Ikincisi ise Sultanın yine kendisine gelen mektubun cevabı olmak üzere Venedikli Jean Dandalo'nun eliyle Papalık makamına verdiği cevabı içermektedir. Sultan bütün Hıristiyan âleminde bulunabilecek en iyi dost ve Hıristiyanların bağıı olduğu efendi şeklinde hitap ettiği muhatabına Ortadoğu'daki Haçıların anlaşmayı bozmasından ötürü veryansın etmektedir. ${ }^{20}$ Söz konusu mektupların bu dönemi bize aktaran İslam kaynaklarından teyidi mümkün olmasa da içeriklerinin bölgedeki siyasî-askerî realiteye uygun olduğu görünmektedir. Sultan özellikle ikinci mektupta mevcut barışın Kudüs ve Sur'daki Haçıllar tarafından bozulduğunu ifade ile artık sorumluluğun kendisinde olmadığını yazmıştır. Zaten sonrasında başlattığı bir dizi askerî harekât neticesinde Hıttin Zaferi (Temmuz 1187) ile Kudüs'ün (Ekim 1187) fethine giden yol açılmış ve dolayısıyla III. Haçlı Seferi için de ilk adım atılmışıı.

Buraya kadar ele almaya çalıştığımı çok yönlü ittifak ve diplomasi teşebbüsleri çalışmamızın ana mihverini teşkil eden Kutsal Roma-Cermen İmparatoru I. Frederich Barbarossa'nın

18 Ottonis de Sancto Blasio, Chronica, ed. A. Hofmeister, in Scriptores Rerum Germanicarum, Hannover: Monvmenta Germaniae Historica, 1912, s. 37. Öte yandan bu durumu yukarıda aktardığımız Arslan Heinrich'in Sultan II. Kılıç Arslan ile 1173'te hac dönüşünde yaptı̆ı̆ görüşsmedeki Hıristiyanlıkla ilgili diyaloglarla ilişkilendirmek mümkündür (bunlarla alakalı bkz. Joranson, a.g.m., s. 201-202, 189n; Özcan, s. 207-211). Heinrich'in gezisinin sonrasında aktardıklarının etkisiyle Sultanın, Hıristiyanlık içerisinde sapkın kabul edilen mezheplerden birine mensubiyeti konusunda birtakım tevatürlerin çıkmış olması muhtemeldir. Nitekim yine bu periyota ait olmak üzere Papa III. Alexander'ın kendisine gelen ve adı geçen Sultanın, Hıristiyanlı̆̆a geçmek isteğine karşlık (Petri Blenensis, Opera Omnia, II, ed. I. A. Giles, Oxonii 1847, (Opuscula) XXI-XXXII; Mathei Parisiensis, Cronicis Maioribus, s. 112, praefatio: W. Wattenbach, ed. Monvmenta Germaniae Historica, tomus XVIII, Hannover: Monvmenta Germaniae Historica, 1888, s. 112) yazılan sahte mektubun (bkz. Altay Tayfın Özcan, “Papa III. Alexandr'ın II. Kılıç Arslan'a Gönderdiği Mektup ve Sultan'ın Hıristiyanlığı Kabulü Meselesi: Mit mi Gerçek mi?", MESOS, Disiplinlerarası Ortaçağ Çalışmaları Dergisi, c. I, sayı. 1, Aralık 2019, s. 5-18.) yanında yine 1186'da ölen çağdaş Roberti de Torigneio (Robert Torigni)'nin (Chronica, ed. Richard Howlett, Chronicles of the Reigns Stephen, Henry Il and Richard I, vol. IV, Londra: Monvmenta Germaniae Historica, 1889, s. 297) deyim yerinde ise doğaüstü mucizelerle süslü ve Hıristiyanlığı yüceltmek motivasyonu ile yazıııı̆ı aşikar II. Kılış Arslan'ın annesi vesilesiyle Hıristiyan olduğuna dair aktarımlar dikkati çekmektedir.

19 Radulfi de Diceto, Opera Historica, (Ýmaniges Historiarum) II, ed. William Stubbs, Londra: Monvmenta Germaniae Historica, 1876, s. 25.

20 Radulfi de Diceto, a.g.e., s. 25-27.

21 Radulfi de Diceto, II, 27. 
Haçlı seferinin Balkan geçişindeki olaylara da direkt etkide bulunmuştur. Öyle ki Almanlar ile Bizans arasında yaşananlarda yukarıda aktarmaya çalıştığımız diplomatik münasebetlerin gölgesi çoğu zaman yekdiğerine karşı şüphe bulutları şeklinde vurmuştur. Bu durum olayları bize aktaran kroniklerin anlatılarına da kimi zaman abartılı komplo teorileri şeklinde yansımıştır. Diğer yandan I. Frederich Barbarossa'nın kara yolunu tercih etmesindeki sebeplerin başında Türkiye Selçuklu Sultanı II. Kılıç Arslan ile arasındaki elçilik teatisi olduğu ve hatta söz konusu münasebetlerin imparatorun Balkanlardaki yolculuğu boyunca da sürdüğü bir vakıadır.

Kudüs'ün, Müslümanlar tarafından fethinin sonrasında Avrupa'da ortaya çıkan şaşkınlık, hayal kırıklığı ve dehşetin fiiliyata yansıması geniş kitlelerin haçı kabul ederek doğuya hareketlenmek üzere hazırlıklara başlaması şeklinde olmuştur. Diğer taraftan kralların da dâhil olduğu üst rütbelilerin sefer hazırlıkları yaptıkları bu dönemde farklı gruplar bağımsız bir şekilde organize olarak çok daha evvelden peyderpey Doğuya doğru yola çıkmışlardır.

Birbirleriyle savaşan İngiltere ve Fransa kralları, Papalığın aracılığı ile Gisors'ta bir araya gelip buna son verirken Kara Avrupası'nın en büyük gücü olan Kutsal Roma-Germen İmparatorluğunun sahibinin ikna edilmesi için yukarıdakiler arasındaki barışın sağlanmasında da aktif rol alan Albano Piskoposu Henri görevlendirilmiştir. Almanca bilmeyen ve tercümanlar vasıtasıyla muhatabına hitap eden bu zat yine de vazifesini başarıyla yerine getirmiştir. Onun çabaları sayesinde imparatorun dışında birçok soylu ve şövalyede haçı kabul etmiştir. ${ }^{22}$ İmparator gerekli planlamaların yapılması adına 27 Mart 1188'de Mainz'de geniş katılımlı bir buluşma tertip etmiştir. Burada haçın kabul edilmesinin akabinde hazırlıkların 23 Nisan 1189 tarihine kadar tamamlanması kararı alınmıştır. ${ }^{23}$

Yapılan hazırlıkların dışında diplomatik çabaların da bütün hızıyla devam ettiği görülmektedir. Nitekim bu yıl içerisinde Bizans İmparatoru II. Isaakios Angelos tarafından gönderilen Logothetes tu dromu24 loannes Dukas başkanlığındaki bir Bizans heyeti Eylül ayında Nüremberg'teki I. Frederich'in huzuruna çıkmışlardır. Görüşme iki taraf arasında geçmişte yaşanmış menfi olayların gölgesinde cereyan etmiş ve heyet II. Isaakios'un, Ortadoğu'yu hedefleyen Alman seferinin kendi egemenlik sahası için bir tehdit olabileceği konusundaki endişelerini I. Frederich'e iletmiştir.

22 Chronica Regia Coleniensis, in Scriptores Rerum Germanicarum, Hannover: Monvmenta Germaniae Historica, 1880, s. 138-139; Arnoldi, Chronica Slavorum, s. 128; Otto Sancto Blasio, a.g.e., s. 45; Ansbertus, Historia de Expeditione Friderici Imperatoris, thk. Josepho Dobrowsky, Prag: Ashgate Publishing, 1827, s. 18, çev. "The History of Expedition of Emperor Frederick", The Crusade of Frederick Barbarossa, The History of Expedition of the Emperor Frederick and Related Texts, çev. G. A. Loud, Burlington, 2010, s. 41; "The History of Pilgrims", The Crusade of Frederick Barbarossa The History of Expedition of the Emperor Frederick and Related Texts, çev. G. A. Loud, Burlington, 2010, s. 143; Roger of Wendower, Flores Historiarum, İng. çev. J. A. Giles, Flowers of History, II, Londra, 1899, s. 63; Edgar N. Johnson “The Crusade of Frederick I and Henry Vl”, A History of the Crusades, II, The Later Crusades 1189-1311, ed. R. L. Wolff - H.W. Hazard (gen. ed. K. M. Setton), Londra, 1969, s. 86-90.

23 Arnoldi, s. 128; Ottonis de Sancto Blasio, a.g.e., s. 44; "The History of Pilgrims", aynı yer.

24 Bizans'ta ulaşım, iletişim ve dış işlerinden sorumlu bakan olup aynı zamanda dış işleri konusunda da imparatorun başdanışmanlığını yapan görevlidir. Bkz. Donald M. Nicol, Bizans ve Venedik, çev. Gül Çağlalı Güven, İstanbul, 2000, s. 40; A. Kazhdan, "Logothetes tou dromou”, The Oxford Dictionary of Byzantium, II, s. 1248. 
Daha önceki Haçlı seferlerinde yaşananlar ve bundan kaynaklı olarak Bizans yöneticilerinin ve ahalisinin zihninde yerleşmiş genel Haçlı imajı dikkate alındığında II. Isaakios'un endişe etmek hususunda pek de haksız olmadığını rahatıkla söylemek mümkündür. ${ }^{25}$ Aynı dönemlerde haçı kabul eden İngiltere Kralı II. Henri'nin, Lüksemburg Arkeodunu Richard Barre eliyle gönderdiği benzer istekleri içeren mektubu da Bizans İmparatorunun endişelerini arttırmış olmalıdır. ${ }^{26}$ Ancak I. Frederich'in gerekli güvenceleri vermesinin sonrasında II. Isaakios, Alman Ordusunun geçiş güzergâhında istenilen erzak ve diğer ihtiyaçları karşılayacağını taahhüt etmiştir. ${ }^{27}$

Bunun dışında sefere kara güzergâhından devam etmek hususunda ısrarlı görünen I. Frederich'i yolculuğun rahat geçeceği hususunda ümitlendiren bir başka gelişme de hemen hemen Bizans heyetiyle aynı dönemlerde huzuruna çıkan Türkiye Selçuklu Sultanı II. Kılıç Arslan'ın elçileri olmuştur. ${ }^{28}$ Ancak Alman İmparatoru her iki heyet ile varılan mutabakatlara karşın bu kadar iyimserlik beslemesi için henüz erken olduğunun şimdilik habersizdi. Nitekim Bizanslıların yanında İstanbul'a yolladığı elçilik heyeti kurtların arasına kuzu olarak gönderildiklerinden (quod tam simplices et fideles legati mittebantur, sicut oves in medio luparum) haberdar değildi. ${ }^{29}$

I. Frederich her şeye karşın kendisinden son derece emin olup bunu da Henri von Dietz adlı elçisini Salâhaddîn'e gönderip ona açık bir savaş ilanında bulunarak göstermiştir. Kudüs'ü ve ele geçirdiği diğer toprakları vermediği takdirde onu bir sonraki Kasım ayında Zoan Ovasında savaşa davetin yanında kendisini Romalı General Crassus ile özdeşleştirerek bu zatın kazandığı zaferler ile muhatabını tehdit etmiştir. Ancak karşı taraftan aldığı cevap haliyle beklediği gibi olmamıştır. Eyyûbî Sultanı ise cevaben savaş için geldiği takdirde her zaman Hıristiyanlardan da kalabalık olan Müslümanlarla onları karşılayacağını, eğer ki barış isterse bölgede Haçılıların elinde kalan yerlerin kendisine teslim edilmesini, bunun yapıldığı takdirde

25 Bizans ahalisi bilhassa II. Haçlı Seferi sırasında Haçlıların saldırganlığından dolayı ciddi sıkıntılar yaşamışlardı. Bununla alakalı bkz. Elizabeth Jefrreys-Michael Jefrreys, "The Wild Beast From the West, İmmediate Literary Reactions in Byzantium to the Second Crusade", The Crusade from the Perspective of Byzantium and the Muslim World, ed. Angeliki E. Lailou-Roy Perviz Mottahedeh, Washington: Hoax Press, 2001, s. 101-116.

26 Radulfi de Diceto, II, 52-53.

27 Niketas Khoniates, Historia, çev. Işın Demirkent, Niketas Khoniates'in Historia'sı (1180-1195), Komnenos Hanedanı'nın Sonu ve Il. Isaakios Angelos Devri, İstanbul: Dünya Yayınları, 2006, s. 207-208; Ansbertus, a.g.e., s. 19, İng. çev. s. 45-46; Brand, Byzantium Confronts the West, s. 176; Johnson, a.g.m., s. 91.

28 Ansbertus, s. 15; “History of Pilgrims”, s. 146; Ottonis de Sancto Blasio, s. 45-46.

29 Ansbertus, s. 20, İng. çev. s. 46. Müellif elçilerin, Bizans heyeti ile birlikte gönderildiğini ifade ederken Chronica Regia Coleniensis'de (s. 145) Bulgar topraklarına girildikten sonra elçilerin yollandığı ifade edilmektedir. Arnoldi (s. 132-133) de buna benzer bir ifade kullanmıştır. Ayrıca bkz. Brand, Byzantium Confronts the West, s. 176; Johnson, a.g.m., s. 91-92; John Freed, Frederick Barbarossa: The Prince and the Myth, New Haven: Yale University Press, 2016, s. 330-331. 
Kutsal Haçı geri verip elindeki Hıristiyan esirleri serbest bırakacağını ve Kudüs'te Hıristiyan rahiplere ibadet için müsaade edeceğini bildirmiştir. ${ }^{30}$

Mektubun içeriğindeki ifadelerin abartılı ve uydurma olabileceği konusundaki (haklı/haksız) şüpheler bir kenara bırakıldığında böyle bir elçiliğin mevcudiyeti bir vakıadır. Zira Eyyûbî sultanına mektubu götüren Henri von Dietz' in adı aynı dönem içerisinde I. Frederich tarafından Bizans İmparatoruna gönderilen elçiler arasında da geçmektedir ${ }^{31}$. Dolayısıyla bu zatın evvela Sultana gidip sonrasında diğer Alman elçileriyle İstanbul'da buluştuğunu düşünmek makul olacaktır. ${ }^{32}$ Hatta adı geçen zat, Türkiye Selçuklularının merkezi Konya'ya da uğrayarak II. Kııı̧ Arslan'a, imparatorun serbest geçiş hakkı ve ordu için pazar yerleri talebini de iletmiştir. ${ }^{33}$

Mainz'daki toplantıda verilen sürenin dolmasının sonrasında emrindeki ordusuyla birlikte 23 Nisan 1189'da Regensburg'tan hareket eden İmparator I. Frederich geride bıraktığı ülkesinin işlerini ise büyük oğlu Heinrich'e havale etmiştir. Kendi adını taşıyan diğer oğlu Swabia Dükü ise onunla sefere katılmıştır. Böylesine büyük bir ordunun denizden taşınamayacağının gerçeği dışında yukarıda zikrettiğimiz sebeplerden ötürü kara yolundan gidilmesi daha uygun görülmüştür. ${ }^{34}$ Teçhizat ve disiplin anlamında mükemmel olmalarının yanında yolculuk sırasında hastalanacaklar için gecikmeye sebebiyet vermesin diye birçok vagon (kapalı araba) inşa edilmiştir ${ }^{35}$. Ancak Alman imparatoru seferi sırasında yaşayacağı uzun süreli gecikmelerin çok başka nedenlerden kaynaklanacağından şimdilik habersizdi.

30 Chronica Regia Coleniensis, s. 140; Petri Belenensis, II, 173-174; Radulfi de Diceto, II, 56-57; "History of Pilgrims", s. 144-145; Roger of Wendower, II, 64-68; Roger de Hoveden, II, 100-102; Itinerarium Peregrinorum Gesta Regis Ricardi, İng. çev. Helen J. Nicholson, Chronicle of Third Crusade A Translation of the Itinerarium Peregrinorum Gesta Regis Ricardi, Londra 1997, s. 49-54; Geoffrey de Vinsauf, Richard of Holy Trinity, Itinenary of Richard I and the Others to the Holy Land, Cambridge: Lulu Press, 2001, s. 22-27.

31 Ansbertus, aynı yer, İng. çev. aynı yer.

32 Münster Piskoposu, Nassau Kontu Rupert, Kont Walram, Dietz Kontu Henri ile mabeyncisi Markvard'tan oluşan bu heyetin yola çıkışı ile alakalı iki farklı görüş bulunmaktadır. Ansbertus (s. 19-29, İng. çev. s. 46) Bizans heyetinin hemen peşinden elçilerini yola çıkardığını söylerken Niketas Khoniates (s. 208-209) ise Bizans sınırlarına girdikten sonra heyetin gönderildiğini yazmıştır.

33 "History of Pilgrims", s. 145.

34 Alman Haçlı Ordusunun mevcuduyla alakalı kaynaklarda birbirini tutmayan farklı rakamlar söz konusudur. Bunlardan Arnoldi (s. 130-131) Tuna Nehri geçilirken yapılan sayımda 50.000 süvari ve 100.000 yaya sayıldığını söyler. Itenerarium müellifi (s. 60) 3000 süvari ve 80.000 yaya, Chronica Regia Colenensis'de (s. 144) 15.000'i seçme 30.000 kişi, İslam kaynaklarından Ebû Şâme (IV, 111) ve İbn Şeddad'ta ( s. 115, İng. çev. 106), İmadeddin el-Katib el-İsfahanî (s. 179) de ise 60.000'i süvari olmak üzere toplamda 300.000 kişi şeklinde sayılardan söz edilmektedir. John Freed (a.g.e., s. 335) 2000 ila 3.000'i süvari toplamda 12.000 ila 15.000 arasındaki bir rakamın en iyi tahmin olabileceğini belirtir. Bu rakamlara orduya daha sonrasında katılan Bulgarları Burgundy, Lorraine ve diğer yerlerden gelen takviyeleri dâhil etmez. Johnson (s. 92) ana gücünü 20.000 süvarinin oluşturduğu 100.000 güçlü askerin olduğu söylenir, demektedir. Bize göre ise bu öncelikle süvariler de dâhil olmak üzere 40.00050.000 arasında bir rakamdır. Zira 100.000 üzerindeki rakamların ikmal, sevk ve idare anlamında yürütülmesinin arz edeceği güçlükleri dikkate almak gerekmektedir. Diğer taraftan I. Frederich'in 1158 senesindeki Milan kuşatmasında 15.000 Alman ve İtalyan şövalyesi ile sayısız yaya askerle yer aldığı söylenmektedir (Freed, s. 172). Alman İmparatorunun, İtalya'da muhatap alınan askerî güçlerle Salâhaddîn Eyyûbî'yi hele de uzun bir yol güzergâhını da dikkat ederek aynı kefeye koymayacağını aşikârdır. Aynı zamanda onun, Eyyûbî Sultanının en çekindiği güç olduğunu da düşündüğümüzde belirttiğimiz rakamlarda bir orduyla yola çıkmış olması muhtemeldir. Itinerarium Peregrinorum Gesta Regis Ricardi, s. 55. 
Nehir üzerinden gemiyle Viyana'ya kadar gelen I. Frederich daha sonra kara yoluyla 25 Mayıs 1189'da Pressburg (bugünkü Bratislava) şehrine ulaşmıştır. Burada kamp kurarak dört gün boyunca ordusunun geride kalan kısımlarının toplanmasını beklemiştir. Pressburg'ta bağlıların ve müttefiklerin katılımılla güçlenen Alman ordusu içerisindeki bazı unsurlar kara güzergâhının meşakkatlerinden sakınarak imparatordan ayrıı deniz yoluyla Ortadoğu'ya gitmeyi tercih etmiş̧lerdir. Bu arada disiplinin korunmasına son derece önem verildiğinden münferit yağmalama olaylarının müsebbipleri elleri kesilmek suretiyle cezalandırılmışlardır. ${ }^{36}$

Alman Ordusu, Macaristan topraklarındaki ilerleyişi sırasında Kral Bela ve eşi tarafından gayet iyi bir şekilde karşılandığı gibi bunlar Gran'da (bugünkü Estergon) I. Frederich ile bir araya gelerek Pentocost (Hamsin) Yortusu kutlamalarını birlikte yapmışlardır. Söz konusu süreci bize aktaran Ansbertus, İmparatora sunulanların yanında diğer liderlere ve ordu mensuplarına da hediyeler verildiğini, ordunun erzak ihtiyaçlarının karşılandığını söylerken Macar Kralının bunu sevgiden mi yoksa korkudan mı (timore vel amore) yaptığının belli olmadığını da ifade etmektedir. ${ }^{37}$ Kaynağın, kralının samimiyeti ile alakalı şüphesine karşın Alman ordusunun Macar topraklarındaki beş haftayı bulan yolculuğu sorunsuz geçmiştir.

Drava Nehrini aşan Almanlar kısa süre önce Macarların eline geçmiş olan Sirmium'a girmiştir. Gerek adı geçen yerleşimde ve gerekse haziran ayının son günlerini geçirdikleri Belgrad şehrinde yılanlar ve sivrisineklerin varlığı dışında herhangi bir aksilikle karşılaşmamışlardır. 1 Temmuz'da ordudaki marangozlara yaptırılan gemilerle Tuna Nehrini geçerek Bizans arazisine adım atmışlardır. Burada Braničhevo şehrinin valisi tarafından da başlangıçta iyi bir kabul görmüşlerdir. ${ }^{38}$ Fakat mevcut durumun aldatıcı olduğu çok geçmeden kendisini belli etmiştir. Almanlar 11 Temmuz'da şehirden ayrılırken Vali başlangıçtaki tavrının tamamen aksine yanlarına verdiği kılavuzların eliyle onları geçilmesi zor yollardan götürerek ilerlemelerini yavaşlatmayı amaçlamıştır.

Alman Ordusu, Niş'e doğru harekete geçildiğinde ise artık her şey tersine dönmüş gibiydi. Arazinin sık ağaçlarla örtülü olmasından da istifade eden çevredeki Grekler, Sırplar, Bulgarlar ve Ulahlar yaptıkları saldırılarla Almanlara rahatsızlık veriyorlardı. Bütün bunların Braničhevo valisinin talimatıyla yapıldığı ve haliyle işin İmparator II. Isaakios'a kadar uzadığına dair yakalananlardan edinilen bilgiler Almanların, Bizanslılara karşı giderek artan bir öfke duymalarına sebebiyet vermekteydi. Özellikle de yapılan saldırılarda zehirli okların kul-

36 Ansbertus, s. 21-25, İng. çev. s. 47-56. Müellif burada ayrıca Alman ordusuna yapılan katıımları tek tek aktarmaktadır.

37 Historia de Expeditione Friderici Imperatoris, s. 25-26, İng. çev. s. 58. Ayrıca bkz., Chronica Regia Coleniensis, s. 144; Arnoldi, s. 129-130; Ottonis de Sancto Blasio, s. 46; Itinerarium Peregrinorum Gesta Regis Ricardi, s. 55-56; Geoffrey Vinsauf, s. 33.

38 Bilhassa Arnoldi (s. 131-132) Braničhevo dükünün, İmparatora iki kulp ile taşınan altından bir gemi hediye ettiğini, Alman ordusunun geçmesi için yolları genişlettiğini ve bir haftalık erzaklarını verdiğini söylemektedir. 
lanılması, faillerin belli bir kasıtla hareket ettiklerini göstermekteydi. ${ }^{39}$ illginç bir şekilde Batılı kroniklerde Bizans ile Salâhaddîn Eyyûbî arasındaki diplomatik münasebetler aktarılırken adı geçen Sultan tarafından elçilik heyeti ile birlikte II. Isaakios'a zehirli yiyecekler gönderildiğine dair bazı aktarımlar mevcuttur.

Buna göre iki taraf arasında zaten var olan dostluk Kudüs'ün fethinin sonrasında da devam etmişti. Yukarıda da belirtildiği gibi II. Isaakios, Sultanı kutlamak üzere ona elçiler göndermişti. Hatta daha sonrasında İstanbul'a gelen Sultanın elçileri diğer mevkidaşlarına nazaran çok daha büyük itibar görmüşlerdi..$^{40} \mathrm{Iki}$ taraf arasında zaten var olan ve yukarıda aktardığımız ittifakın varlığı dönemin şahidi İslam kaynaklarınca da anlatılmaktadır. Nitekim hepsi söz birliği etmiş gibi Bizans İmparatoru II. Isaakios'un, Haçlıları engellemek isteğine karşın bunu başaramadığı ancak ikmal hususunda onları oldukça zorladığı ifade etmişlerdir.41 Öte yandan bu durum zaten Kudüs'ün elden çıkmasının şokunu yaşayan ve çözüm yerine öncelikle evvela bir günah keçisi aramayı alışkanlık haline getirmiş Batılılar için gayet uygun bir ortam meydana getirmekteydi.

Öyle ki Chronicon Magni Presbyteri'de iki tarafın gerçekleştirdikleri karşılıklı elçilik teatisi sırasında Bizans İmparatorunun, Sultan Salâhaddîn'den aldığı hediyelerin arasında 8.000 yük zehirli un, 3.000 yük zehirli buğday (et sex milia modiorum farinae toxicatae, et tria milia modiorum frumenti simiter toxicati) ve yine zehir dolu bir kap bulunduğu şeklinde bir bilgi geçmektedir. ${ }^{42}$ Hatta biraz daha sonrasında bu durumun giderek paranoya halini aldığı ve başka bir kaynakta Almanların, Bizanslıların verdikleri şaraplardan kendilerinin zehirlenmediklerini aksine bunları içirdikleri düşmanlarının acılar içinde öldükleri yazılmıştır. ${ }^{43}$ Yine bir diğer kronikte Eyyûbî Sultanının kendisine müttefik edindiği Bizans İmparatoruna 800 Türk okçusu gönderdiğini şeklindeki bilgi de elçilik ile birlikte gelen zehir ve zehirli oklarla vurulan

39 Ansbertus, s. 29, ing. çev, s. 60. Yine Itanareium (s. 56) müellifi de benzer şekilde Alman ordusunun ezilmesi ya da engellenmesi için bütün bunları İmparator Isaakios'un organize ettiğini yazmıştır. Arnoldi (s. 131) ise ilginç bir şekilde zehirli ok saldırılarının Sırplar tarafından yapıldığını ve yiyecek aramaya çıkan 500 hizmetçinin bu şekilde öldürüldüğünü ertesi gün ise bölgenin hâkiminin (Sırp Jupanı Stephan Nemanya) itaatini sunmak üzere İmparatorun yanına geldiğinden bahsetmektedir. Ayrıca İmparator Manuel'in 1180'deki ölümü sırasında Bizans'ın tabiiyetinden çıkan adı geçen Sırp Jupanının bu bölgede etkinlik göstermesi de Arnoldi'nin aktardıklarını doğrular niteliktedir. Aynı şekilde Ansbertus (s. 28, 30, 33, 35, İng. çev. s. 60-62, 64, 66) eserinin farklı yerlerinde Alman Ordusuna karşı zehirli oklarla yapılan saldırılara dair kayıtlar bulunmaktadır.

40 Radulfi de Diceto, II, 59.

41 İbn Şeddad, a.g.e., s. 132-133, İng. çev. s. 121-122; Ebû Şame, IV, 111-114; İbn el-Esîr, XII, 48. Yine Yerli Hıristiyan kaynaklarımızdan Gregory Abu'l-Farac'da (Abu'l-Farac Tarihi, II, çev. Ömer Rıza Doğrul, Ankara 1999, s. 454) Almanya Kralı, İstanbul'a geldiğinde Yunanlılar onu ilerlemekten alıkoydular. Bu yüzden kral onlarla döğüştü ve onları mağlup etti. Yunanlılar da ona boyun eğdiler ve yol verdiler şeklinde kısa ama benzer bir kayıt yer almaktadır. Niketas Khoniates (s. 209 v.d.) de belli bir süre sonrasında İmparatorun muhataplarını engellemek çabası içine girdiğinden bahsetmektedir.

42 s. 512, İng. çev. s. 155. Ancak aynı olaydan bahseden Radulfi de Didecto (II, 60) da zehir olayı ile alakalı bir bahis yoktur.

43 Ansbertus, s. 54-55; İng. çev. s. 81-82. 
Almanların açıklaması gibidir. ${ }^{44}$ Ancak Sultan Salâhaddîn'in yakın danışmanları arasında yer alan kaynaklarımızda böyle bir bilginin mevcudiyetine rastlanmaz. Zehirli oklar meselesinin gerçeklik içermesi olasılığının yüksekliğine karşın yine de bunun organize bir fiil olduğunu söylemek pek doğru bir yargı olmayacaktır. Muhtemelen bahse konu kaynaklar içine düştükleri zorlukların da etkisiyle karşılarındaki ittifakın etkisini göstermek amacıyla böyle bir anlatıma başvurmaları ihtimal dâhilindedir. Ayrıca Akka önlerindeki mücadelelerde asker açısından sıkıntı yaşayan ve bunu da Halife'ye yazdığı mektubunda açıkça ifade eden ${ }^{45}$ Sultan'ın bahsedilen rakamdaki bir birliği Bizans imparatoruna göndermesi şartlar gereğince düşünülemez. Öte yandan onun bütün siyasî-askerî kariyeri sırasında düşmanlarına dahi ortaya koyduğu adaletli ve hoşgörülü tavrının da böyle bir harekete engel teşkil edeceğini burada belirtmek gerekmektedir.

Bir başka husus ise Bizans İmparatorluğunun Manuel Komnenos'un ölümünden beridir isyanlarla çalkalanan Balkan coğrafyasındaki etkinliğinin derecesinin ne olduğudur. Hatta I. Frederich ile sürekli görüşen ve onu İstanbul üzerine yürümeye kışkırtan Sırp, Bulgar ve Ulah asi liderlerinin dahi bölgedeki otoritesi sorgulanır niteliktedir. Böylesi bir hengâmede Alman Ordusuna yapılan saldırıların büyük bir kısmının bu düzensizlikten istifade etmeye çalışan haydutlardan geldiğini düşünmek daha doğru bir tespit olacaktır. Bizans'ın olaylara menfi yöndeki müdahalesi ise bize göre Braničhevo valisinin eliyle Almanları geçilmesi zor yollara sevk etmekten ibarettir.

Aslında benzer bir durum karşı saftaki Bizans için de geçerlidir. Nitekim İmparator, her şeye rağmen Almanların Filistin'e değil kendisi üzerine yürüdüğünü düşünmekteydi. Bu sebeple de kendisine aktarılan bir kehanette onların Xylokerkos Kapısı'dan (Belgrad Kapısı)'sından şehre gireceği anlatıldığı için burasını ördürmüştü. Hatta kaynakta onun eline yeni yapılmış okları alarak Blakhernai Sarayı'nın penceresinden bakıp buradan ok atarak Almanları yok edeceğini söylediği ve böylelikle kendisini gülünç duruma düşürdüğü ifade edilmektedir. ${ }^{46}$

Yukarıdan itibaren anlatmaya aktarmaya çalıştı̆ııız söz konusu rivayetler Bizans ile Haçlıların arasında var olan ve aradan geçen süreçte daha da keskinleşmiş bir düşmanlığın ürünüdür. Her iki taraf da birbirini olduğundan daha kötü göstermenin yanı sıra yaptıkları ve yapılanlar için mazeret gösterebilmek adına fırsatııı bulduklarında yekdiğerini böylesine abartılı hikâyelerin muhatabı yapmaktan geri durmamıştır. Aslında bütün bunlar 15 sene sonrasında meydana gelecek olayların da bir habercisidir.

Tekrardan Alman Ordusunun ilerleyişine döndüğümüzde yanlarındaki yolu bilen Macarların desteği ile 27 Temmuz'da Niş'e ulaşan imparatoru burada Sırp Büyük Jupanı Stephan Nemanya ve kardeşi karşılamıştı. İmparator Manuel'in 1180'deki ölümü sonrasında Bizans

44 Chronicon Montis Sereni, Monvmenta Germaniae Historica, tomvs: XXIII, ed. E. Ehrenfeuchter, Hannover 1874, s. 161.

45 Ebû Şâme, II, 185.

46 Niketas Khoniates, s. 212-213; Radulfi de Didecto, aynı yer. 
ile tabiiyet bağlarını koparan bu zat I. Frederich'in gelişini hâkimiyet sahasını genişletmek ve siyasî bir ittifak için fırsat olarak görmüştü. 0 sıralarda işgal etmiş olduğu Niş’te muhataplarını iyi bir şekilde istikbal edip hediyelere boğan Stephan Nemanya aynı şekilde güzel bir karşılık görmüştü. Bu durum haklı olarak zaten güvensizliklerin pençesindeki II. Isaakios Angelos'u gelenlerin niyetleri konusunda iyice endişelendirmiş olmalıdı. ${ }^{47}$ Mamafih Nemanya'nın talepleri hedefinden sapmak istemeyen I. Frederich tarafından kabul görmemişti. Benzer şekilde Bulgar asiler de I. Frederich ile anlaşma zemini bulmak üzere Alman ordugâhına gelip gidiyorlardı. ${ }^{48}$

İlginç olan bir husus ise Bizans İmparatorunun, Almanların gelişi sırasında İstanbul'da bulunmayışıdır. Nitekim II. Isaakios o sıralarda Philadelphia şehrinde isyan eden Theodoros Mankaphas isyanını bastırmak üzere Anadolu'ya geçmişti. ${ }^{49} \mathrm{I}$. Frederich'in elçileri de bir süre onun gelişini beklemek zorunda kalmışlardı. Bir sene öncesinde elçilerinin Nüremberg'de Alman İmparatorunun huzuruna çıkmış olmalarına karşın II. Isaakios'un, muhatabını biraz daha geç beklediği ihtimal dâhilindedir. Nitekim Almanlar da onun, İstanbul'da olmadığını Macar Kralı'nın gönderdiği elçilerden öğrenmişlerdir. ${ }^{50}$

İmparator, İstanbul'a dönmesinin hemen ardından kabul ettiği elçileri efendilerinin Sırplarla münasebatından endişe ederek tevkif ettirmişti. Bunun sonrasında Alman ordugâhına gönderilen Bizans elçilerinin de vazifelerinin tamamen aksine hareket etmeleriyle iki taraf arasındaki ilişkiler biraz daha çıkmaza girmişti. Öyle ki loannes Dukas ve Andronikos Kantakuzenos adlı elçiler I. Frederich'i Romalılara karşı kızdırdılar. ${ }^{51}$ Akabinde ise olaylar domino taşı etkisiyle gelişmeye başladı. Sonuçta edilen yeminler bozuldu ve gerekli yiyecek malzemesinin sağlanması aksadı. ${ }^{52}$ Teyakkuza geçen Bizans askerî gücü, Bulgaristan'daki sık ormanlık sahada ve geçitlerde pozisyon aldığı gibi Alman ordusundan yiyecek aramak üzere ayrılana da saldırmak emrini almıştı. Böylece zihinlerde mevcut olan asıl niyetler artık tam manasıyla açığa çıkmıştı.

Bu arada Filibe'ye doğru yola çıkan Alman Ordusu ise Bizanslıların yönlendirmesiyle ya da yalnızca soygun ve talan gayesiyle saldırılar düzenleyen gruplara karşı kayıplar vererek ilerlemeye devam ediyordu. Ayrıca sıtma başta olmak üzere salgın hastalıklar da can kayıplarının sayısını arttırmaktaydı. Erzak imkânlarının kısıtlanmasından ötürü ordudaki fakir yaya askerler arasındaki kayıplar da yükselmişti. Çünkü bunlar yanlarındaki mevcut erzakı önceden tükettikleri için yeni durumdan haliyle ciddi şekilde etkilenmişlerdi. Bölgenin ahalisi ise bulunabilecek ikmal ve iaşe maddeleriyle birlikte şehirleri terk edip dağlara çekilmişti.

47 Chronicon Magni Presbyteri, s. 510, İng. çev. s. 150. Arnoldi (s. 132) ise Braničhevo Valisinin; Almanların geldiğini ve eğer onlara müsaade ederse onu tahtından edip ülkesini elinden alacaklarına dair II. Isaakios'a bir mektup yazarak onu endişelendirdiğini aktarmaktadır. Ayrıca bkz. Brand, s. 177; Jason, a.g.m., s. 102.

48 Ansbertus, s. 30, 33, 55, 58, İng. çev. 61-62,64,83-85. Ayrıca bkz. Johnson, s. 99-100.

49 Niketas Khoniates, s. 202-206.

50 Ansbertus, s. 28-29, Ing. çev. s. 60-61.

51 Niketas Khoinates, s. 209; Ansbertus (s. 33, İng. çev. s. 64) ise onların yine kendilerine karşı ikiyüzlü bir tavır takındıklarını, yol güzergâhı boyunca rehberlik ve pazar yerleri açılacağının güvencesini verdiklerini söylemektedir.

52 Niketas Khoinates, aynı yer. 
Bu arada Almanlar erzaklarının bulunduğu kolu saldırganlara karşı süvarilerin dışında tatar yayları (arbalet) ile silahlanmış askerler ile korumaya aldıkları gibi yakaladıklarını da idam edip teşhir ederek korku salmaya çalışıyorlard..$^{53}$

İmparator I. Frederich yürüyüşün öncesinde ordusunu üç kısma bölerek öncü birliklerinin başına oğlu Swabia Dükünü getirmişti. Babasıyla aynı adı taşıyan bu zatın gayretleriyle Alman Ordusu birbiri ardına muhtemelen Bizans kuvvetleri tarafından tutulan üç tahkimli geçidi aşıp daha rahat bir yürüyüş imkânı bulduğu gibi çevreden elde ettikleri erzak sayesinde ikmallerini sağlayabilmişlerdi. Nihayetinde 14 günlük bir yolculuğun sonrasında yine sakinleri tarafından terk edilmiş ve erzak bakımından boş olan Sofya şehrine ulaşmışlardı. Bir süre dinlenip güç toplayan I. Frederich bazı Bizans güçlerinin yolu üzerindeki geçitleri tahkim ettiğini haber almıştı. Bunun üzerine bizzat ordusundan bir kısım süvarinin başına geçerek rakiplerinin üzerine yürümüştü. Fakat karşısındakiler savaşmayı göze alamayarak çekilmeyi tercih etmişlerdi. Böylece Bulgaristan geçitlerinin tamamın aşmayı başaran Almanlar sekiz haftanın sonunda 20 Mayıs'da Circuviz denilen yere inmişlerdi. Burası düz bir araziydi. ${ }^{54}$

I. Frederich'i Circuviz'de II. Isaakios'un serbest geçiş hakkını reddettiğini bildiren bir mektubuyla gelen yeni bir Bizans heyeti beklemekteydi. Daha Almanya'dan harekete geçmeden evvel bu konuda anlaşmış olduğunu düşündüğü muhatabından böyle bir karşlık almak onu kızdırmıştı. İstanbul'a gönderdiği elçilerin hapsedildiğini öğrenmesi ise kızgınlı̆ının öfkeye dönüşmesine sebebiyet vermişti. ${ }^{55}$

İmparatorlarını öfkesini çevredeki araziyi yağmalayarak dindirmek isteyen ${ }^{56} \mathrm{Alman}$ ordusu 26 Mayıs'ta Filibe'ye ulaşmıştı. Bu şehirde bulunan erzak depolarında ele geçirilenler ve yapılan talandan elde edilenlerle birleştiğinde ordu ikmal ve iaşe yönünden oldukça rahatlamıştı. Bunun etkisiyle I. Frederich, Filibe'de kışlamaya karar vermişti. Çünkü Bizans İmparatoru ile tam bir anlaşmaya varmadan hareket emek niyetinde değildi. Hatta şehirdeki ikameti sırasında farklı senaryolar için de hazırlık yapmaktan geri durmamıştı. Nitekim Almanya'daki oğlu Heinrich'e mektup yazarak Bizans üzerine bir saldııı için Papalıktan gerekli

53 Ansbertus, s. 35, ìng. çev. s. 65-66.

54 Ansbertus, s. 34-38, İng. çev. s. 65-68.

55 Ansbertus, s. 39, İng. çev. s. 69; Khoniates (s. 212), II. Isaakios'un muhatabına sert bir mektup yazarak barış istememesini ve erkekçe karşısına çıkması bildiren bir mektup yazdığını söyler. Müellif burada I. Frederich'in bölgedeki Bizans komutanı Protostrator Manuel Kamytzes'e mektuplar yazarak ilerleyişinin engellenmesinden dolayı şikâyetlerini bildirdiğini belirtir. Chronicon Magni Presbyteri (s. 510, İng. çev. s. 150) de ise Bizans İmparatorunun gönderdiği elçiler aracılığı ile Almanlardan ele geçirecekleri yerlerin yarısını istediği şeklinde bir bilgi yer almaktadır.

56 I. Frederich o zamana değin çeşitli bahanelerle geçtikleri yerlerde yağma yapan ordu mensuplarını cezalandırmaktan kaçınmamıştı. Hatta verdiği ağır cezalar sebebiyle bu türden olaylar ciddi şekilde azalmıştı. Ancak elçilerinin hapse atılması ve bir süre beklemesine karşılık serbest bırakılmamaları üzerine Alman İmparatoru bilhassa Filibe'ye geldikten sonra Bizans arazisini yağmalamak üzere ordusuna müsaade vermiştir. Bkz. Ansbertus, s. 33-34, İng. çev. s. 64-65; Arnoldi, s. 132-133. Brand (s. 181-182) da Alman İmparatorunun muhatabı anlaşmaya zorlamak üzere bu yağmalara giriştiğini ifade etmektedir. Ayrıca bkz., Freed, s. 339-340; Ebru Altan, Haçı Ordularının Anadolu'da Selçuklu Topraklarına Son Girişi: Imparator Friedrich Barbarossa'nın Haçlı Seferi (1189-1190), Tarih Dergisi, sayı:68 (2018/2), İstanbul 2018, s. 19-20. 
onayın alınmasını ayrıca İtalyan denizci şehir devletleriyle iletişime geçerek bunların filolarıyla mart ayı içerisinde kendisiyle İstanbul önlerinde buluşmalarının sağlanmasını istemişti. ${ }^{57} \mathrm{Bu}$ sırada İstanbul'dan, Almanları kışkırtan haberler gelmeye devam ediyordu. Söylenenlere göre Patrik Dositheios; Ayasofya'da bir Grek 100 Haçlıyı öldürdüğü takdirde Tanrı́nın bağışlanmasını garanti edecektir şeklinde vaazlar vermekteydi. ${ }^{58}$

Öte yandan II. Isaakios, Protostrator Manuel Kamytzes emrindeki Bizans birliklerine Almanları sürekli şekilde rahatsız etmeleri için emir vermişti. ${ }^{59}$ Adı geçen komutan Filibe yakınlarındaki tepelerin yamaçlarında pusuya yatarak sabahleyin yiyecek aramaya çıkan gruplara saldırmayı planlamıştı. Ancak Almanlar bölgedeki Ermeniler aracılığı ile bundan haberdar edildikleri için şehirden yaptıkları ani bir saldırı ile Kamytzes'in birliklerini kaçmak zorunda bırakmışlardı. Bizanslılar bir ara savaşmak için duraksadılar ise de kayıplar vererek çekilmişlerdi. Hatta birçoğu atlarını ve silahlarını yitirmiş bir halde karargâhlarına dönebilmişti. Zira hızlı şekilde hareket etmek istediklerinden buna dayanamayan atları çatlamıştı. ${ }^{60}$ Edindikleri bu acı tecrübenin neticesinde artık Almanlara fazla yaklaşmaya cesaret edemeyen Bizans birlikleri onları uzak mesafeden takibi sürdürmüşlerdi.

Alman İmparatoru ise güvenlik, erzak temini ve karşısındakilere isteklerini kabul ettirmek amacıyla çevredeki Bizans şehirlerine saldırıları arttırmıştı. İlk olarak Bizans ordusundaki paralı Türk birlikleri tarafından savunulan Beroe (Eski Zağra, Stara Zagora) şehri muhafızlarının kaçması neticesinde ele geçirilip yağmalanmış ve dört gün sonrasında da terk edilmişti. Akabinde Filibe'nin 60 km kuzeyinde yer alan Scribention (günümüzde Sopot) ve Brandovei ve Perna şehirlerinin dışında toplamda on kale daha Almanların eline geçmişti. ${ }^{61} \mathrm{Bu}$ arada evvelden beridir Bizans idaresi ile sorunlar yaşayan bölgedeki Bulgarlar ve Ermeniler, onlarla gönüllü işbirliği içerisine girmişlerdi.

II. Isaakios, Almanların Filibe'ye yerleşmelerinin sonrasında giriştikleri yağmalara aynı sertlikte mukabele etmenin imkânsızlığını anlamıştı. Dolayısıyla I. Frederich'in kendisine gönderdiği yeni bir elçilik heyetinin gelişini de fırsat bilerek öncelikle esir tuttuğu ilk heyetteki üyeleri serbest bırakmıştı. Daha sonrasında yanlarına kendi elçilerini katarak onları Filibe'ye yollamıştı. Bunlar hep birlikte 28 Ekim'de Alman imparatorunun yanına varmışlardı.

Ancak tekrardan başlayan görüşmeler bir kere daha karşılıklı güvensizliklerin gölgesinde kaldığı gibi üstelik şimdi taraflar arasında yekdiğerine karşı nasıl hitap edileceği şeklinde bir sorun ortaya çıkmıştı. Öncelikle esaretten dönen elçileri dinleyen Alman İmparatoru; Patriğinin kışkırtıcı vaazlarını, Eyyûbî sultanının aynı dönemlerde İstanbul'a gelen elçilerine verilen değeri öğrendiğinde muhatabına fazla güvenmemesi gerektiğini tekrardan tecrübe etmişti.

57 Ansbertus, s. 42-43, İng. çev. s. 71-72.

58 Ansbertus, s. 43, İng. çev. s. 72.

59 Niketas Khoniates, s. 212-216, 217.

60 Ansbertus, s. 44-45, İng. çev. s. 73; Niketas Khoniates, s. 216-217.

61 Ansbertus, s. 45, İng. çev. s. 74. 
Bu sebeple Çanakkale Boğazı'ndan Anadolu'ya geçmeden önce kendisini ve ordusunu garantiye almak üzere II. Isaakios'tan rehineler istemişti. Zira yolculukları boyunca yaşadıkları ve karşısındakine duyduğu güvensizlik sebebiyle boğaz geçişi sırasında ordusunun her iki kıyıya dağıldıkları sırada hücuma uğrayıp imha olunmasından çekiniyordu. ${ }^{62}$

Bütün bunlar yetmiyormuş gibi imparatorluk unvanının kullanılmasıyla alakalı taraflar arasında ucu bir hayli eskiye giden bir tartışma yeniden başlamıştı. II. Isaakios bu ve sonraki elçilik heyetleriyle birlikte yolladığı mektuplarında imparator unvanını kendi şahsı için kullanıp I. Frederich'e kral diye hitap etmişti. ${ }^{63}$ Bize göre bu II. Isaakios'un muhataplarını geciktirmek adına yaptığı yeni bir hamleden başka bir şey değildir. Öyle ki askerî anlamda Almanları durdurmanın imkânsızlığını ve kendisi için çok daha tehlikeli sonuçlar doğurabileceğini gördüğünden işin siyaset-diplomasi mecrasında sürdürülmesini daha uygun bulmuş olmalıdır. Çünkü uzun yıllardır devam eden bu konunun siyasetin dışında sosyal ve mezhepsel yönleri bulunmaktaydı. Böylesine geniş bir sorunlar yumağının da bir anda çözümü imkânsızdı.

Nitekim konumuz dâhilindeki olayları bize aktaran kaynaklarda Almanlar kendilerini Romalı ve II. Isaakios'u Grek kralı (Regem Greciae) ${ }^{64}$ olarak nitelendirirken Bizans tarafı da aynı şekilde kendilerini Romalı muhataplarını ise Alman ya da barbar olarak ifade etmekteydiler. ${ }^{65}$ Bunun yanında Almanlar zaman zaman Bizans İmparatoru için İstanbul Kralı (Regem Constantinopolitanum) bazen de İstanbul İmparatoru (İmperatoris Constantinapolitani) unvanını da kullanmışlardır. ${ }^{66}$ Ancak sonuçta iki taraf da kendisini gerçek imparator olarak gördüğünden bu tartışmanın tam da II. Isaakios'un istediği gibi uzaması muhtemeldi.

Fakat her şeye rağmen taraflar; Almanların, Çanakkale Boğazı'ndan geçmeleri, Bizans'ın ise onlar için pazar yerleri ve gemiler tedarik etmesi konusunda aralarında mutabakat sağlamışlardı. Fakat tabi ki Almanların muhataplarına güven duymak hususunda halen ciddi şüpheleri mevcuttu.

62 Ansbertus, s. 48-49, İng. çev. s. 76-77.

63 Büyük Roma İmparatorluğunun hayatta kalabilen yegâne varisi durumundaki Doğu Roma (Bizans) zaman içerisinde söz konusu mirastaki hakkını vurgulamak üzere hamlelerde bulunmuş ise de pek de başarılı olamamıştır. Avrupa siyasetinin yeni sahipleri onu, kendi etki sahalarından uzak tutmak adına ellerinden gelen çabayı göstermişlerdir. Bu arada Bizans İmparatorluğu'nun 451 senesindeki Kadıköy Konsili'yle birlikte Hıristiyanlık üzerindeki hegomonyasını sonlandırdığı Papalık da bunun intikamını 800 senesinde Charlemagne'ye imparatorluk tacı giydirerek almıştır. Böylece Bizans'ın karşısına mukabil bir imparator çıkarmışlardır. Bu durum Bizans'ı, Avrupa siyasetinden uzaklaştırma çabalarının bir sonucu olmuştur. 0 sıralarda zaten ikonoklast hareketin ortaya çıkardığı iç çatışmalarla meşgul olan Bizans başlangıçta bunu kabullenmek istemedi ise de nihayetinde 812 senesinde I. Mikhael Rangabe (811-813) gönderdiği elçiler vasıtasıyla Charlemagne'yi imparator olarak selamlamıştır. Hatta bunun öncesinde dönemin Bizans İmparatoriçesi Irene ile Charlemagne'nin evliliği ve böylece doğu ve batının yeniden tek bir imparatorluk haline getirilmesi fikri dahi söz konusu olmuştu. Ancak imparatoriçenin azli buna müsaade etmemişti. Bkz., Georg Ostrogorsky, s. 170-173; John Julius Norwich, Bizans II, 18-19; Usta, Sorularla Bizans Imparatorluğu, s. 89-90.

64 Chronica Regia Coleniensis, s. 145.

65 Niketas Khoniates, s. 207-208, 210, 212, 217, 219.

66 Ansbertus, s. 48, İng. çev. s. 76; Arnoldi, s. 132; Chronicon Magni Presbyteri aynı yer; Ottanis de St. Blasio, s. 47. 
Bütün bu görüşmeler devam ederken Chronicon Magni Presbyteri'de Alman Ordusunun Filibe'deki sayısız cesetten çıkan kokular sebebiyle tehdit içinde olduğuna dair bir bilgi aktarılmaktadır ${ }^{67}$ Bu durum bir salgın hastalığın sonucu olmalıdır. Dolayısıyla da I. Frederich daha evvelki kararının aksine ilerlemeye karar vererek 5 Kasım'da Edirne'ye gitmek üzere şehirden ayrıııı̧tır. Ordusundan bir kısmını ise ağırlıklarla birlikte Filibe'de bırakmıştır.

8 Kasım'da Blisimos (Belozem) şehrine ulaşan Alman İmparatoru burada yedi gün kadar kaldıktan sonra bir meseleyi görüşmek üzere Filibe'ye dönmüştür. Ordu yeniden yola çıktığında ise bazı Macar kontları ayrılmak isteklerini bildirmeleri üzerine onlara onay veren Frederich akabinde ilerlemeye devam etmiştir. Macarlar 19 Kasım'da Alman ordusunu terk ederek geri dönmüşlerdir. Bunun sonrasında Alman İmparatoru muhtemelen hem bu konuyla alakalı hem de damadı olan II. Isaakios'un yaptıklarından şikâyet etmek üzere Macar Kralı Bela'ya elçiler göndermiştir. ${ }^{68}$

22 Kasım'da Edirne'ye ulaşan Alman Ordusu bir yandan burada kışı geçirmek üzere hazırlıklar yaparken diğer taraftan da çevredeki şehirleri zapt ve yağmaya başlamıştı. ilk olarak Regensburg Piskoposu Konrad emrindeki birliklerle Probaton şehrini ele geçirmiş ve içerisinde bol miktarda erzak bulmuştu. Swabia Dükü Frederich ise güçlü bir birlik tarafından savunulan Dimetoka'ya saldırı 24 Kasım'da şehri ele geçirmeyi başarmıştı. Yağmalanan şehirde 1500 kişi öldürülmüştü. ${ }^{69} 7$ Aralık'ta ise Filibe'de bırakılan ağırlıklar ve ordunun orada kalan kısımlarından bazıları da Edirne'ye ulaşmıştı.

Öte yandan Bizans birlikleriyle zaman zaman yapılan çatışmalara karşın Almanlar bölgede askeri üstünlüklerini kesin şekilde ortaya koymuşlardı. Bu arada Sırbistan Jupanı Stephan Nemanya ve Bulgar asiler de I. Frederich'e hala İstanbul üzerine gittiği takdirde bütün askeri güçleriyle yanında yer alacaklarını bildiren elçiler göndermeye devam ediyorlardı. Fakat Kudüs'e gitmek kararında ısrarcı olan imparator onların tekliflerini geri çevirmekte tereddüt etmemişti. Ancak Bizanslıların üzerinde kurduğu baskıyı da sürdürmekten vazgeçmemişti.

Öyle ki Alman birliklerine ikmal ve iaşe sağlanması yönünden verdiği destek sebebiyle Ordunun Kahyası (dispensator exercitus) $)^{70}$ lakabını alan oğlu Swabia Dükü Frederich, Makedonya tarafına doğru ağır bir yağma akını yapmıştı. Başkentinin hemen yanı başına yerleşen muhatabının yaptıklarına daha fazla direnmenin ortaya çıkaracağı tehlikelerin farkında olan Isaakios nihayetinde yeniden elçiler göndererek istenilen rehineleri vereceğini, pazar yerlerinin oluşturulup boğaz geçişinde gerekli bütün gemileri tedarik edeceğini bildirmek zorunda kalmıştı.

Alman imparatoru şartları kesinleştirmek üzere elçilerini İstanbul'a gönderirken saldırılarına devam eden birlikleri Arkadiopolis (günümüzde Lüleburgaz) şehrini yağmalayıp karşılarına çıkan Ulahlar ve Kumanlardan müteşekkil bir Bizans birliğini de mağlup etmişlerdi. ${ }^{71}$

67 Aynı yer, İng. çev. s. 153.

68 Ansbertus, s. 52-53, İng. çev. s. 80.

69 Ansbertus, s. 53-54, İng. çev. s. 81; Chronica Regia Coleniensis, s. 146-147.

70 Ansbertus, s. 58, İng. çev. s. 85.

71 Ansbertus, s. 62-63, İng. çev. s. 88-89. 
Şehirleri yağmalanan ve ahalisi katledilen II. Isaakios neticede aşağıda aktarılan şartlar dâhilinde I. Frederich ile kesin bir anlaşmaya varmıştı. Buna göre:

1) II. Isaakios malların yağmalanması, şehirlerin imha edilmesi, insanların ölümü ve yaralanmasıyla alakalı her türlü tazminat talebinden gönüllü olarak vazgeçecektir.

2) Bizans İmparatoru Almanların kendilerinin ve bineklerinin geçişi için her türlü araç ve gemiyi sağlayacaktır. Ayrıca bunlar I. Frederich'in kontrolünde olacaktır. Ancak Alman İmparatoru da Bizans topraklarına hiçbir zarar verilmeyeceğinin ve hiçbir geminin İstanbul üzerine yönelmeyeceğinin garantisini verecektir.

3) Abydos ile İstanbul arasındaki sahadaki Bizans'a ait bütün gemiler limanlarda demirli kalacak, herhangi bir ihanet ihtimaline karşın bu periyotta denize açılmayacaklardır.

4) Almanlar, Bizans arazisinde kaldığı süreçte İstanbul İmparatorunun ordusu onlara dört günlük mesafeden daha yakına gelmeyecektir.

5) II. Isaakios geçiş sırasında kıyıya yakın iki şehri Almanlara bırakacak. Ancak Almanlar da buradaki ahaliye ve şehre hiçbir şekilde zarar vermeyecektir.

6) Bu vaatlerin yerine getirilmesini sağlamak üzere II. Isaakios muhatabına özel seçilmiş 22 rehine verecektir (burada hanedana mensup ya da yakın rehinlerin adları sayılmaktadır). ${ }^{72}$ Esirler Alaşehir'e ulaşıncaya kadar I. Frederich'in yanında kalacak ve sonrasında zarar verilmeden geri gönderileceklerdir.

7) Eğer ahali Almanlara yiyecek temininde gönülsüz davranıp bu iş için görevlendirilmiş Pansebastos, orduya yiyecek temin edemediği takdirde Almanlar herhangi birinin toprağını elinden almamak kaydıyla uygun gördükleri gibi davranmakta serbesttir.

8) İstanbul İmparatoru, Almanlara yardım eden Grek, Ermeni ya da Latin herkesi affedeceğini, onlara imparatorluk lütfunu bahşedeceğini garanti eder.

9) Alışverişlerde bir gümüş mark 5.5 hyperpera'ya denk olacaktır. Eski ve yeni arasında fark gözetilmeksizin hperpera 120 staminaya eşit kabul edilecektir.

10) Alman ordusu için geçiş sırasında ve sonrasında mümkün olan yerlerde iyi pazarlar kurulacak. Ürünler, II. Isaakios'un belirleyeceği makul fiyatlara hiçbir hile olmaksızın buralarda satılacaktır.

11)II. Isaakios, Münster Piskoposu ve yanındakilerin elçilik görevleri sırasında uğradıkları zararları tazmin edecektir.

12) Şehrin ve imparatorluğun en iyi 500 adamı Patrik Dositheius'un da hazır bulunacağı Ayasofya'daki bir törende bu şartlar üzerine yemin edecektir.

13) Anlaşmada da Ökümenik Patrik'in de imzası yer alacaktır.

72 Arnoldi (s. 133) rehinlerin 50 kişi olduğunu söylemektedir. 
14) Ayrıca Bizans İmparatoru savaş başladığından beri karada ya da denizde ele geçirdiği hacı ya da tüccar olsun herkesi serbest bırakacaktır. ${ }^{73}$

Yapılan bu anlaşma öncekilere nispeten daha kesin bir karakter arz etmekteydi. Alman Ordusundaki birçok ileri gelenin halen İstanbul'a saldırmak hususundaki heveslerine karşın I. Frederich şartlara uymak kararındaydı. Bulgarların ve Sırpların ısrarlı tekliflerini de bu sebeple tekrardan ret etmişti. 15 Ocak'da Alman Ordusunun, Filibe'de kalan diğer birlikleri de ana orduya katılmak üzere buradan ayrılmışlar ve 6 Şubat günü Edirne'ye varmışlardı.

14 Şubat'da Alman karargâhına gelen İmparator II. Isaakios'un elçilerinin hemen akabinde 17 Şubat'ta önce Türkiye Selçuklu Sultanı II. Kılıç Arslan ve ardından da onun büyük oğlu Kutbeddin Melikşah'ın elçileri I. Frederich'in yanına gelmişlerdi. Bunların verdiği dostluk mesajları da Alman İmparatorunun bir an önce Anadolu'ya geçmek isteğinde etkili olmuş olmalıdır. Nitekim daha öncesinde gönderdiği Wiesenbachlı Gottfried ile birlikte yanına ulaşan Sultan Kılıç Arslan'ın elçisi, I. Frederich'e pazar yerleri için de güvence vermişti. ${ }^{74}$

Burada Sultanın dışında büyük oğlu Melikşah'ın da Alman imparatoruna elçiler göndermesi gayet dikkat çekicidir. Zira II. Kılıç Arslan ülkesini 11 oğlu arasında pay etmiş olup bunlar arasında ciddi bir rekabet söz konusuydu. ${ }^{75}$ İçlerinden en büyüğü olan Melikşah muhtemelen kendisini yaşlı babasının veliahtı olarak gördüğü için Alman İmparatoru ile diplomatik münasebete girmek hususunda tereddüt göstermemiştir.

Alman Ordusundaki yolculuk hazırlıklarının devam ettiği sırada 24 Şubat'ta çıkan bir fırtına ciddi sıkıntı meydana getirmişti. Ancak her şeye rağmen 27 Şubat'ta istenilen rehinelerin de gelmesinin sonrasında yağan şiddetli yağmurların oluşturduğu seller ve çamurlu yolların dışında hareket etmek için herhangi bir engel kalmamıştı. 1 Mart'ta Alman Ordusunun öncüsü olarak Edirne'den ayrılan Swabia Dükü Frederich'in bir gün sonrasında İmparator da kalan birliklerle şehri terk etmişti. Yağmurların sebebiyet verdiği ağır şartlara rağmen yürüyüşüne devam eden Alman Ordusu nihayetinde 21 Mart'ta Bolayır'ı geçerek Gelibolu'ya ulaşabilmişti. Bu arada özellikle de binek hayvanlarının yiyecekleri tükenmişti. Ancak fırtınadan dolayı İstanbul'a gitmekte olan mısır ve erzak yüklü bir Venedik kadırgasının kıyıya vurmasıyla bu mesele hiç umulmadık şekilde çözülmüştü. ${ }^{76}$

Almanlar gruplara ayrıldıktan sonra ilk olarak 22 Mart'ta Swabia Dükü kendi birlikleriyle boğazdan karşı kıyıya geçmişti. Ardından ordunun kalan kısımları yağan şiddetli yağmurlara rağmen Bizans gemileri tarafından Anadolu'ya aktarılmış ve son olarak da 28 Mart günü I. Frederich beş kadırganın eşliğinde karşı kıyıya adım atarak geçişi tamamlamıştı. ${ }^{77}$ İmparator

73 Ansbertus, s. 64-66, İng. çev. s. 90-92.

74 Ansbertus, s. 67, İng. çev. s. 92-93; Chronica Regia Coleniensis, s. 147.

75 Bkz. Turan, s. 225-229.

76 Ansbertus, s. 70-71, İng. çev. s. 95.

77 Ansbertus, s. 71, İng. çev. s. 95-96; Niketas Khoniates, s. 222; Chronica Regia Coleniensis, s. 148. Arnoldi (s. 133) ise Alman Ordusunun üç günde karşı kıyıya geçtiklerini yazmıştır. 
hemen akabinde yanında bulunan rehinelerden 13 tanesini serbest bırakmış ise de diğer beşini şartlarda ifade edildiği üzere Alaşehir'e ulaşıncaya kadar yanında tutmuş ve buraya geldiğinde geriye göndermiştir. Alman Ordusu, imparatorlarının gelişinden bir gün sonra Anadolu içlerine doğru harekete geçerek yolculuklarının ikinci bölümüne başlamışlardır.

Sonuç olarak; Alman Haçlı Ordusunun Regensburg'tan Gelibolu'ya kadar uzanan yolculuklarının bu ilk safhasında Bizans İmparatorluğu ile yaşadıkları olayları geçmişin bir yansıması şeklinde görmek mümkündür. Öyle ki yüzyıllara dayanan siyasî ve mezhepsel ayrışma ile bütünüyle iki zıt kutup haline gelen Bizans ile Batı Dünyasının arasındaki girift ilişkiler örüntüsünde kapanıştan önceki son perde oynanmıştır. Burada gücünü tamamen yitirmiş birincilerin, Eyyûbîlerle yaptıkları ittifak muhatapları tarafından hainlik ve ihanet olarak yorumlanmış ise de söz konusu durum coğrafya ve dönemin siyasî şartlarının gerekliliklerinin yanında Batı dünyası ile arada mevcut kökleşmiş güvensizlik duyguları sebebiyle son derece tabi bir durumdur. Ele aldığımız konuyu bize aktaran gerek Bizans gerekse Latin kaynaklarının anlatılarındaki temel husus da hep bu güvensizlik olmuştur.

Ortaya çıkan netice ise III. Haçlı Seferlerinin kaderine direkt etkide bulunmuştur. Zira Eyyûbî Sultanı Salâhaddîn'in en çok çekindiği güç Alman İmparatoru I. Frederich ve ordusuydu. Ancak Almanların, Bizans'ın Balkanlardaki arazisinden geçişleri sırasında yıpratılmaları ve geciktirilmelerinin ardından Anadolu'da da benzer bir akıbete maruz kalmaları Eyyûbî Sultanına kendisi için hayati öneme sahip zamanları kazandırmıştır. Üstüne İmparator I. Frederich'in Silifke suyunu geçerken ölümü ve ordusunun dağılması da onları Salâhaddîn için bir tehlike olmaktan tamamen çıkarmıştır. Öyle ki Swabia Kontu Frederich'in emrindeki çok cüz'i bir kuvvetle bölgeye ulaşan Almanların Akka önlerinde cereyan eden mücadelelerde etkinlik sağlayacak bir durumları olamamıştır.

Peer-review: Externally peer-reviewed.

Conflict of Interest: The author has no conflict of interest to declare.

Grant Support: The author declared that this study has received no financial support.

Hakem Değerlendirmesi: Dış bağımsız.

Çıkar Çatışması: Yazar çıkar çatışması bildirmemiştir.

Finansal Destek: Yazar bu çalışma için finansal destek almadığını beyan etmiştir.

\section{Bibliyografya}

Abu'l-Farac, Gregory, Abu'l-Farac Tarihi, II, çev. Ömer Rıza Doğrul, Ankara: TTK, 1999.

Altan, Ebru, “Bizans'a Karşı Illk Haçlı Seferi Girişimi ve 1108 Devol Anlaşması”, Prof. Dr. Mehmet Ipşirli Armağanı, I, İstanbul: Timaş Yayınları, 2013, s. 107-117.

Altan, Ebru, “Haçlı Ordularının Anadolu'da Selçuklu Topraklarına Son Girişi: İmparator Friedrich Barbarossa'nın Haçlı Seferi (1189-1190)”, Tarih Dergisi, sayl: 68 (2018/2), İstanbul 2018, s. 15-30. 
Anna Komnena, Alexiad, Malazgirt'in Sonrası, çev. Bilge Umar, İstanbul: İnkılap Yayınevi, 1996.

Ansbertus, Historia de Expeditione Friderici Imperatoris, thk. Josepho Dobrowsky, Prag: Ashgate Publishing, 1827; İng. çev. "The History of Expedition of Emperor Frederick", The Crusade of Frederick Barbarossa, The History of Expedition of the Emperor Frederick and Related Texts, İng. çev. G. A. Loud, Burlington: Ashgate Publishing, 2010.

Arnoldi, Choronica Slavorum, thk. I. M. Lappenberg, in Scriptores Rerum Germanicarum, ed. G. H. Pertz, Hannover: Monvmenta Germaniae Historica, 1868.

Brand, Charles M., Byzantium Confronts the West 1180-1204, Cambridge: Ashgate Publishing, 1968.

Brand, Charles M., "The Byzantines and Saladin 1185-1192: Opponents of the Third Crusade" Speculum, vol. 37, no. 2 Nisan 1962, s. 167-181.

Cameron, Averil, The Byzantines, Oxford: Princeton University Press, 2006.

Chronica Regia Coleniensis, in Scriptores Rerum Germanicarum, Hannover: Monvmenta Germaniae Historica, 1880.

Chronicon Magni Presbyteri, Annales Reicherspergenses, ed. W. Wattenbach, Monvmenta Germaniae Historica (MGH), XVII, ed. G. H. Pertz, Hannover 1861; Ing. çev. G. A. Loud, The Crusade of Frederick Barbarossa, The History of Expedition of the Emperor Frederick and Related Text, Burlington: Monvmenta Germaniae Historica, 2010.

Ebû Şame, Kitabü Ravzateyn fi ahbari'l-devleteyn, en-Nuriyye ve'l-Selahiyye, III, IV, thk. İbrahim Zeybek, Beyrut 1997.

Freed, John, Frederick Barbarossa: The Prince and the Myth, New Haven: Yale University Press, 2016.

Geoffrey de Vinsauf, Richard of Holy Trinity, Itinenary of Richard I and the Others to the Holy Land, Cambridge: Lulu Press, 2001.

Hamilton, Bernard, The Leper King and his Heirs, Baldwin IV and the Crusader Kingdom of Jerusalem, Cambridge: Cambridge University Press 2000.

loannes Kinnamos, Historia, çev. Işın Demirkent, loannes Kinnamos'un Historia'sı (1118-1176), Ankara, TTK, 2001.

İbn el-Esîr, el-Kamil fi't-Tarih, XI, nşr. C. J. Tornberg, Beyrut: Dâru Sadır, 1979.

İbn Şeddad, en-Nevadir es-Sultaniyye fi'l-Mehasin el-Yusufiyye, thk. Cemal Şeyyal, Kahire: Mektebet'ülHâncî, 1994; İng. çev. D. S. Richards, The Rare and Excellent History of Saladin, Burlington: Ashgate Publishing, 2002.

İmadeddin el-Katib el-İsfahanî, el-Feth el-Kussi fi'l-feth el-Kudsî (Hurub-i Salâhaddîn ve Feth-i Beyti'lMakdis), t.y.

Itinerarium Peregrinorum Gesta Regis Ricardi, İng. çev. Helen J. Nicholson, Chronicle of the Third Crusade A Translation of the Itinerarium Pregrinorum Gesta Regis Ricardi, Londra: Ashgate Publishing 1997.

Jefrreys, Elizabeth- Jefrreys, Michael, "The Wild Beast From the West, İmmediate Literary Reactions in Byzantium to the Second Crusade", The Crusade from the Perspective of Byzantium and the Muslim World, ed. Angeliki E. Lailou-Roy Perviz Mottahedeh, Washington: Hoax Press, 2001, s. 101-116.

Johnson, Edgar N., "The Crusade of Frederick I and Henry VI", A History of the Crusades, II, The Later Crusades 1189-1311, ed. R. L. Wolff - H.W. Hazard (gen. ed. K. M. Setton), Londra, 1969, s. 87-122.

Joranson, E., "The Palestine Pilgrimage of Henry the Lion", Medieval and Historiographical Essay in Honor of James Westfall Thompson, ed J. L. Cate-E. N. Anderson, Chicago, 1938, s. 146-225.

Kazhdan, A., “Logothetes tou dromou”, The Oxford Dictionary of Byzantium, II, 1247-1248.

Makrizî, es-Sulûk li-ma'rifeti düveli'l-müluk, I, thk. Muhammed Abdülkadir Ata, Beyrut 1997. 
Mathei Parisiensis, Cronicis Maioribus, s. 112, praefatio: W. Wattenbach, ed. Monvmenta Germaniae Historica, tomus XVIII, Hannover: Monvmenta Germaniae Historica, 1888.

Nicol, Donald M., Bizans ve Venedik, çev. Gül Çağlalı Güven, İstanbul, 2000.

Niketas Khoniates, Historia (loannes ve Manuel Komnenos Devirleri), çev. Fikret Işוltan, Ankara, TTK, 1995.

Niketas Khoniates, Historia, çev. Işın Demirkent, Niketas Khoniates'in Historia'sı (1180-1195), Komnenos Hanedanı'nın Sonu ve II. Isaakios Angelos Devri, İstanbul: Dünya Yayınları, 2006.

Norwich, John Julius, Bizans II, Yükseliş Dönemi (MS. 803-1081), çev. Selen Hırçın Riegel, İstanbul: Dünya Yayınları, 2013.

Norwich, John Julius, Bizans, III, Gerileme ve Çöküş Dönemi (MS. 1082-1453), çev. Selen Hırçın Riegel, İstanbul: Dünya Yayınları, 2013.

Neocleous, Savvas, "The Byzantines and Saladin: Some Further Argument", Al-Masaq: Islam and Medieval Mediterranean, 25:2, 2013, s. 204-221.

Neocleous, Savvas, "Byzantine-Muslim Conspiracies Against the Crusades: History and Myth", Journal of Medieval History, 36 (2010), s. 253-274.

Ostrogorsky, Georg, Bizans Devleti Tarihi, çev. Fikret Işıltan, Ankara: TTK, 1995.

Ottonis de Sancto Blasio, Chronica, ed. A. Hofmeister, in Scriptores Rerum Germanicarum, Hannover: Monvmenta Germaniae Historica, 1912.

Özcan, Altay Tayfun, “Lübeckli Arnold'un Choronica Slavorum Adlı Eserinde Arslan Heinrich'in, II. Kılıç Arslan'ı Ziyareti (1173) Bahsi ve Kayıtlarının Bazı Sorunları Üzerine”, Selçuklu Araştırmaları Dergisi, no. 1, Konya 2016, s. 191-216.

Özcan, Altay Tayfun, “Papa III. Alexandr'ın II. Kılıç Arslan'a Gönderdiği Mektup ve Sultan'ın Hıristiyanlığı Kabulü Meselesi: Mit mi Gerçek mi?”, MESOS, Disiplinlerarası Ortaçağ Çalışmaları Dergisi, c. I, sayı. 1, Aralık 2019, s. 5-18.

Petri Blenensis, Opera Omnia, II, ed. I. A. Giles, Oxonii: Monvmenta Germaniae Historica, 1847.

Phillips, Jonathan, Defenders of the Holy Land, Relations between the Latin East and the West 1119 1187, Oxford: Oxford University Press, 1996.

Radulfi de Diceto, Opera Historica, (Ýmaniges Historiarum) II, ed. William Stubbs, Londra: Monvmenta Germaniae Historica, 1876.

Roberti de Torigneio (Robert Torigni), Chronica, ed. Richard Howlett, Chronicles of the Reigns Stephen, Henry II and Richard I, vol. IV, Londra: Monvmenta Germaniae Historica, 1889.

Roger de Hoveden, Annals of Roger de Hoveden, II, İng. çev. Henry T. Riley, Londra, 1853.

Roger of Wendower, Flores Historiarum, İng. çev. J. A. Giles, Flowers of History, II, Londra 1899.

Runciman, Steven, Haçlı Seferleri Tarihi, II, III, çev. Fikret Işıltan, Ankara: TTK, 1992.

Turan Osman, Selçuklular Zamanında Türkiye, İstanbul: Boğaziçi Yayınları, 1993.

Usta, Aydın, Sorularla Bizans Imparatorluğu, İstanbul: Yeditepe Yayınevi, 2016.

Usta, Aydın, Doğunun ve Batının Hakimleri, Selçuklular (Gerçek Hikayeler ve Anekdotlar), İstanbul: Yeditepe Yayınevi, 2019.

Usta, Aydın, Çıkarların Gölgesinde Haçlı Seferleri, İstanbul: Yeditepe Yayınevi, 2016. 
